\title{
Surface treatments to modulate bioadhesion: A critical review
}

\author{
D.G. Waugh, C. Toccaceli, A.R. Gillett, C.H. Ng, S.D. Hodgson and J. \\ Lawrence \\ Laser Engineering and Manufacturing Research Centre, Faculty of Science \\ and Engineering, University of Chester, Chester CH1 4BJ, UK
}

Corresponding Author:

D.G Waugh

Laser Engineering and Manufacturing Research Centre

Faculty of Science and Engineering

University of Chester

Chester

Cheshire

CH1 4BJ, UK

e-mail: d.waugh@chester.ac.uk

Tel: +44(0) 1244513930

\begin{abstract}
On account of the recent increase in importance of biological and microbiological adhesion in industries such as healthcare and food manufacturing many researchers are now turning to the study of materials, wettability and adhesion to develop the technology within these industries further. This is highly significant as the stem cell industry alone, for example, is currently worth $£ 3.5$ million in the United Kingdom (UK) alone. This paper reviews the current state-of-the-art techniques used for surface treatment with regards to modulating biological adhesion including laser surface treatment, plasma treatment, micro/nano printing and lithography, specifically highlighting areas of interest for further
\end{abstract}


consideration by the scientific community. What is more, this review discusses the advantages and disadvantages of the current techniques enabling the assessment of the most attractive means for modulating biological adhesion, taking in to account cost effectiveness, complexity of equipment and capabilities for processing and analysis.

\section{Keywords: Surface treatment; surface engineering; wettability; biological adhesion.}

\section{Introduction}

With an ageing worldwide population and the increased focus on health and food safety, the need for manipulation of biological adhesion is ever increasing and is borne out from social, economic and health implications. This being said, there is an increasing interest in surface treatment/engineering of materials specifically regarding manipulating tissue engineering [1-9] and bacterial adhesion [10-14]. In a generalized sense, the development of technologies for the manipulation of biological and microbiological adhesion can be viewed in Figure 1. The surface treatment parameters for the technique will affect the topography and/or the surface chemistry which, in turn, modulates the wettability characteristics of the material and subsequently modulates the biological/microbiological cell response to that particular material. In many instances the cell response can then be analysed to control the surface treatment parameters to elicit a specific biological and/or microbiological cell response [15]. This will ultimately one day provide clinicians and industrialists with a selection of surface treatment techniques and corresponding parameters to produce tailored surfaces for specific, accurate and repeatable tailoring of biological and microbiological cell response.

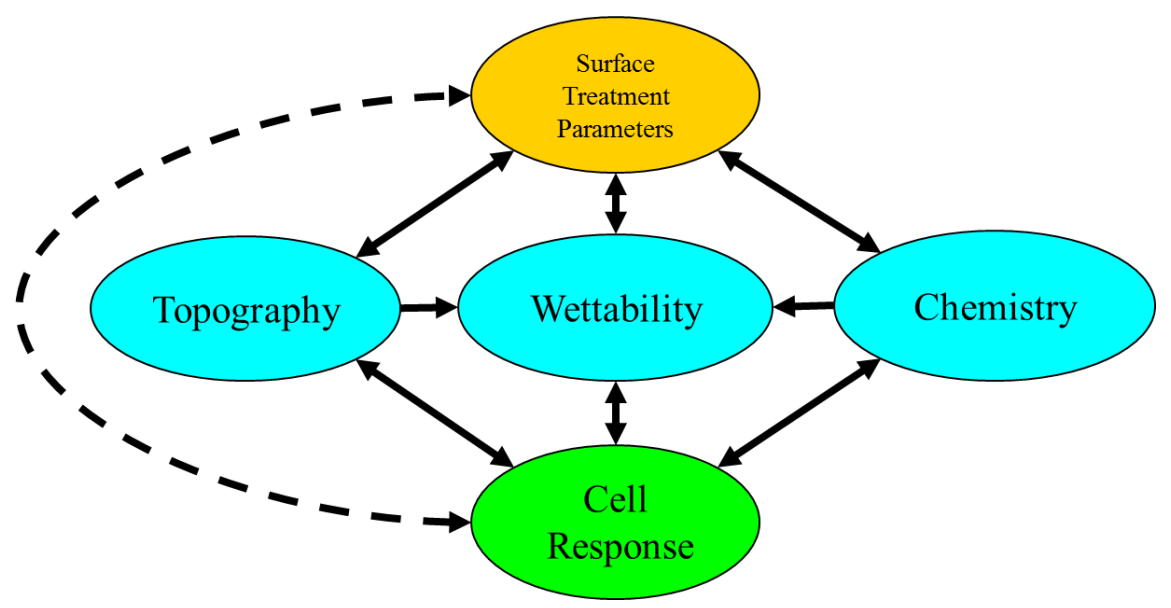

Figure 1: Diagram showing the relationships between the main parameters of surface treatments and the manipulation of biological adhesion.

In environments where eukaryotic cells compete with bacterial cells for domination of the surface, the drive to manufacture new surfaces as an integral component of advanced biomaterials remains an increasingly high 
research priority [16]. This is to elicit the desired eukaryotic cell response whilst inhibiting bacterial growth at the same time. It is no surprise that there is a difference between the attachment of bacterial cells compared to eukaryotic cells. That is, bacterial cells adhere on the surfaces as a colony whereas single eukaryotic cells can adhere to surfaces independently of each other [16]. Comparing the response of mammalian and bacterial cells to surface topography, the relatively small size of bacteria might be thought to be a favourable factor for bacteria to sense nanometre topographical features [16]. However, bacteria have a rigid characteristic shape that does not deform to accommodate the topographical constraints of surfaces like mammalian cells do. This could potentially hinder the interaction between the bacterium and the topographical surface, specifically against features with typical dimensions less than the size of the bacterium, limiting the possibility for bacteria to sense them [17].

With regards to tissue engineering, it has been realized that many untreated potential biomaterials possess poor adhesion characteristics and, as such, have poor biomimetic properties leading to them being rejected by the human body [7]. So, in order to optimize their adhesion characteristics for their use in biological environments, a vast number of techniques and methods have been developed. These techniques range from surface topography modification $[18,19]$ to surface chemistry modification [20-22] and have even given rise to increased interest in using polymers as biomaterials [1, 10, 21, 23]. Taking the stem cell industry alone, its global worth is estimated to increase by $£ 3$ billion over the next 4 years [24]. To this end, such surface engineering research will make inroads in to providing a pharmaceutical scale process for manufacturing platforms upon which cells can be grown and investigated. This is based on the fact that biological cells can discriminate against subtle variations in the surfaces properties of materials $[1,25,26]$ and with an increased interest in the manipulation of stem cells $[6,27]$.

With regards to microbiology, bacteria have evolved to become considerably more capable at adapting to their environmental conditions, increasing the likelihood for them to attach and form biofilms (complex 3dimensional communities). This has resulted in major health concerns and economic burden in both hospital and industrial environments [11, 12, 28], so much so that it has been estimated that hospital acquired infections cost the United Kingdom's National Health Service (NHS) up to f1000 million per annum [29]. Microbial activity and biofilms are also well known to cost the industry billions of pounds each year due to product contamination, energy losses and equipment damage. The physical properties of a surface regulates bacterial cell attachment and physiology, therefore affecting the early stages of biofilm formation. Surfaces which prevent this bacterial fouling through their physical structure represent a key area of research for the development of antibacterial surfaces for many different environments.

On account of the apparent and current importance of surface engineering in biological and microbiological adhesion, this paper will introduce and discuss the main competing surface engineering techniques and the 
current-state-of-the-art application of these surface engineering techniques to manipulate biological adhesion.

\subsection{The Role of Wettability in Biological and Microbiological Adhesion}

Applying the theory of wetting to biomaterials has given rise to a number of theories and hypothesis which attempt to explain biological adhesion. In particular, this has led to the development of two main hypotheses. The first makes an effort to determine a correlation between the surface energy and the biofunctionality of the material. The second takes in to account the contact angle and adhesion properties and relate them to the bioactivity of the material. In both instances, it has been seen that the surface energy and wetting nature is related to the biological response [30]. Researchers such as van Oss et al [31] have conducted various studies to determine an approach which can quantify the bioactivity and biofunctionality of a material. Even though such a theory would be ground-breaking, these investigations have been unable to produce a fully quantifiable theory which predicts the bioactivity of a material with sufficient certainty. Through further research, though, it is highly believed that the role of wettability can be used to allow one to predict how a material can operate within biological and microbiological environments.

Based on the fact that it is only the uppermost atomic layers of a material which comes in to contact with the biological and microbiological environment, it is only the first few molecular layers which drive the biofunctionality of the material [30, 32]. With this in mind, the cell-surface interactions are conducted in a small, discrete region which has been named the interface and, by implementing surface treatments, the adhesion characteristics of materials can be controlled [33-37]. Through investigations of surface treatments to effect biological adhesion it has been determined that surface thermodynamics plays an important role in many of the adhesion processes [38-41]. This is due to the multicomponent nature of adhesion and the way in which surface thermodynamics enables such a multi-component system to be efficiently and sufficiently analysed. When accounting for adhesion it is also usually necessary to consider the wettability characteristics of the material and it has been shown that this factor can aid as a potential prediction mechanism for biological adhesion [1, 3, 6, 42]. From this, the surface free energy of a material, along with the characteristic resulting contact angle evaluated with a liquid, can be directly related to the determination of bioactivity and cell adhesion.

It has been widely observed that poor cell spreading on hydrophobic materials and good cell spreading on those materials exhibiting hydrophilic characteristics can arise in both the absence and presence of pre-adsorbed serum proteins [32]. Furthermore, research has shown that protein adsorption is more likely to occur with hydrophobic materials in comparison to those that are hydrophilic. From this, one can deduce that the exchange of a pre-adsorbed protein by another protein would be more likely to occur on a hydrophilic material. In addition, adsorption-induced conformational variations occur with greater frequency on hydrophobic materials and cell adhesion reaches an optimum on those materials 
exhibiting mild hydrophilic tendency with water contact angles, $\theta$, of around $60^{\circ}$. Interestingly in contrast to eukaryotic cells, it has been found that intermediate $\theta$ of $30^{\circ}$ to $100^{\circ}$ elicits enhanced microbial attachment, giving rise to a higher probability of biofilm formation [43]. Therefore, surfaces which are either superhydrophilic $\left(\theta \leq 10^{\circ}\right)$ or superhydrophobic $\left(\theta \geq 150^{\circ}\right)$ are more likely to prevent the attachment of bacteria.

\section{Various Surface Treatments}

\subsection{Laser Surface Treatment}

The principle of laser surface treatment is the modification of a surface as a result of interaction between a beam of coherent light, with high power density, and the surface within a specified atmosphere (vacuum or processing gases). Laser surface treatment methods include laser surface alloying, laser surface melting and laser surface structuring [44] and can be implemented to modify the adhesion characteristics of materials [45]. These techniques offer advantages such as flexibility and productivity of the process, the optical system can be adapted to the shape or complexity of the product, reproducibility and reliability of quality of the treated surface and the ease of production line incorporation and automation of the procedure. The disadvantages can include poor absorption of laser wavelengths giving rise to inefficient or no processing, and that some lasers have a non-homogeneous energy distribution in the laser beam.

Laser surface melting (see Figure 2(a)) results in a refinement of the surface structure due to rapid quenching from the melt. Surface melting involves the use of a high intensity beam to scan the surface of a substrate in a gas atmosphere. The heat input from the laser has to be sufficient to promote melting, so that the structure of the surface can be modified. At temperatures far above the melting temperature, hydrodynamic motion can reshape and redistribute material. Radial temperature gradients on the order of $102-104 \mathrm{~K} / \mathrm{mm}$ can develop in melt pools, causing convective flows to circulate material [46]. By increasing the temperature whilst decreasing the liquid's surface tension, the liquid is pulled from the hotter to the cooler regions [47]. Convective and thermocapillary forces can then cause significant deformations that are frozen in during solidification [48, 49].

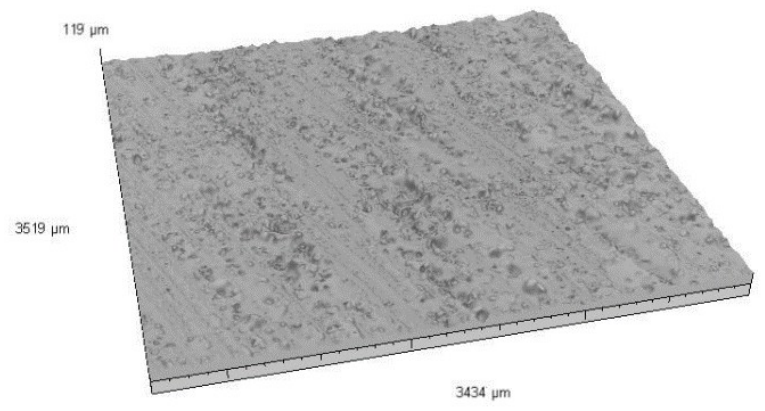

(a) 
(b)

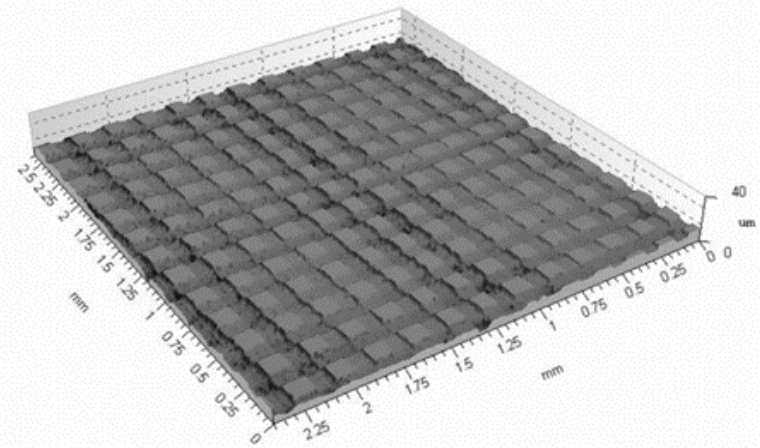

Figure 2: Typical examples of laser surface engineering for (a) $\mathrm{CO}_{2}$ laser melting of Poly(methyl methacrylate) (PMMA) and (b) UV laser micromachining of nylon 6,6.

Vast improvements in both laser technology and processing techniques have resulted in the possibility of micro-processing to produce surface patterning using direct beam scanning [2]. This gives rise to considerably smaller features being achievable with an improved quality of surface modification. Laser surface structuring arises from the ability to focus the laser beam onto specific areas of the target material giving rise to evaporation/ablation of the material, leaving behind unique surface features [50]. Much of the research conducted over the last 10 to 20 years in laser structuring of materials has employed ultra-violet (UV) lasers, excimer lasers in particular. An example of such a surface is given in Figure 2(b). The UV laser beam-material interaction gives rise to ablative photo-decomposition and subsequently gives rise to etching of the material surface. Research such as that conducted by Callewaert et al. [51] showed that UV laser direct writing of the material eradicates the requirement for photo-masks, making the process easier and keeping the running costs low. Leading on from this, Pfleging and Bruns [52] and Duncan et al. [53] showed that two and 3-D topographies can be efficiently achieved using excimer lasers. With both investigations it was highlighted that the laser-induced micro-patterns had significant potential applications in the manipulation of biological adhesion. To speed up the surface patterning process, it has been shown that diffractive phase masks can be utilized [54]. This is significant as it also allows one to design the mask to compensate for any non-linearities in the lasermaterial response. Having said this, for ablation of any material to take place the ablation threshold, which is material and wavelength dependent, must either be met or exceeded [44,55] and this can be a limiting factor for laser material processing.

Laser types other than UV excimer lasers can also be implemented to produce micro-patterns within materials, an example of which can be seen in Figure 2(b). Another example, micro-patterning on stainless steel, is given in Figure 3. Chan et al. [56] and Tiaw et al. [18] showed that by implementing Nd:YAG lasers periodic linear and dot patterns could be generated on polymeric material surfaces. As Nd:YAG lasers were used, the machining could be carried out without the need of a photo-mask or a 
focusing lens and can be seen as a highly attractive materials processing technique if one wanted a very flexible equipment set-up. Applying this technology to biological adhesion, Nd:YAG lasers have been shown to micro-pattern polymeric materials and subsequently manipulate cell adhesion [57, 58]. Furthermore, other laser types such as $\mathrm{CO}_{2}$ and femtosecond lasers have been employed to produce laser-induced surface patterns which could be utilized to manipulate biological and microbiological adhesion. For instance, the investigation undertaken by Dadbin [59] showed that it was possible to modify the wettability characteristics, by inducing topographical and surface chemistry changes, of low-density polyethylene (LDPE) film by using a pulsed $\mathrm{CO}_{2}$ laser. In addition, the research carried out by Aguilar et al. [60] allowed one to see that direct micro-patterning of biodegradable polymers can be carried out by both excimer and femtosecond lasers indicating that femtosecond lasers give results equivalent to those achieved by the excimer laser. Skordoulis et al. [61] carried out laser ablation using $\mathrm{XeCl}, \mathrm{CO}_{2}$ and Nd:YAG lasers and concluded that it was not recommended to utilize any of these three lasers for ablating nylon 6,6 due to the induced thermal damages that arise from laser processing. In addition, the process of laser patterning of polymers can be optimized by producing polymers specifically for the task. These optimized polymers are manufactured such that they are more sensitive to the incident laser beam [62], making them more sensitive in comparison to those polymeric materials which are currently commercially available.
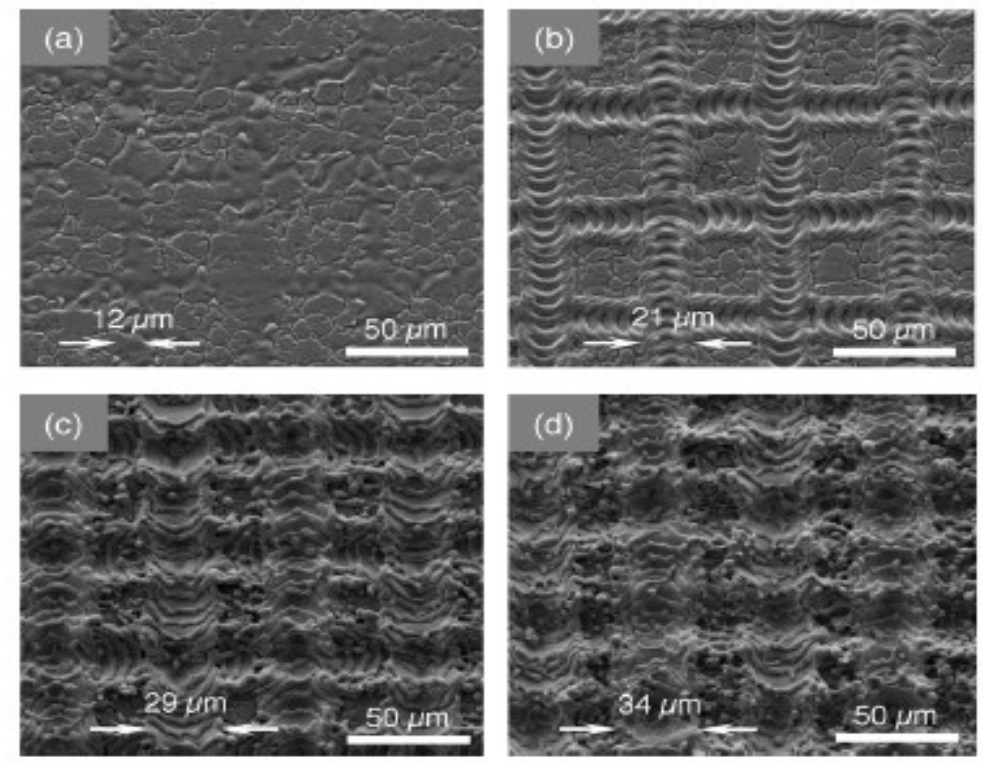

Fig. 2. SEM images of laser textured surfaces irradiated with the same line separation of $50 \mu \mathrm{m}$ for various powers. (a)-(d) Laser fluence of $25, \beta 3,40,48 \mathrm{~J} / \mathrm{cm}^{2}$, respectively.

Figure 3: SEM images of ns laser surface processing of stainless steel with laser fluences of (a) $25 \mathrm{Jcm}^{-2}$, (b) $33 \mathrm{Jcm}^{-2}$, (c) $40 \mathrm{Jcm}^{-2}$ and (d) $48 \mathrm{Jcm}^{-2}$ all with a scanned line separation of $50 \mu \mathrm{m}$. Re-printed from [63]

Femtosecond lasers have several distinct advantages for material nanoprocessing, including high resolutions (down to $25 \mathrm{~nm}$ ), non-contact 
interaction and they can be applied to any substrate [64]. High-precision material processing with femtosecond laser pulses has been demonstrated [65] which allowed the fabrication of complicated two- and three-dimensional nanostructures with a structure size on the order of a few hundred nanometres. Nanostructures are produced at fluences close to the melting threshold of the material, short laser pulses with duration of less than a nanosecond (ns) melt only the micro-protrusions on the target surface giving rise to efficient formation of nanostructures [66]. These nanostructures will affect the hydrophobicity of surfaces potentially creating a superhydrophobic surface $\left(\theta \geq 150^{\circ}\right)$ [67], a phenomenon known as the lotus effect. A typical nano-ripple structure on silicon, following femtosecond laser surface engineering, is given in Figure 4.

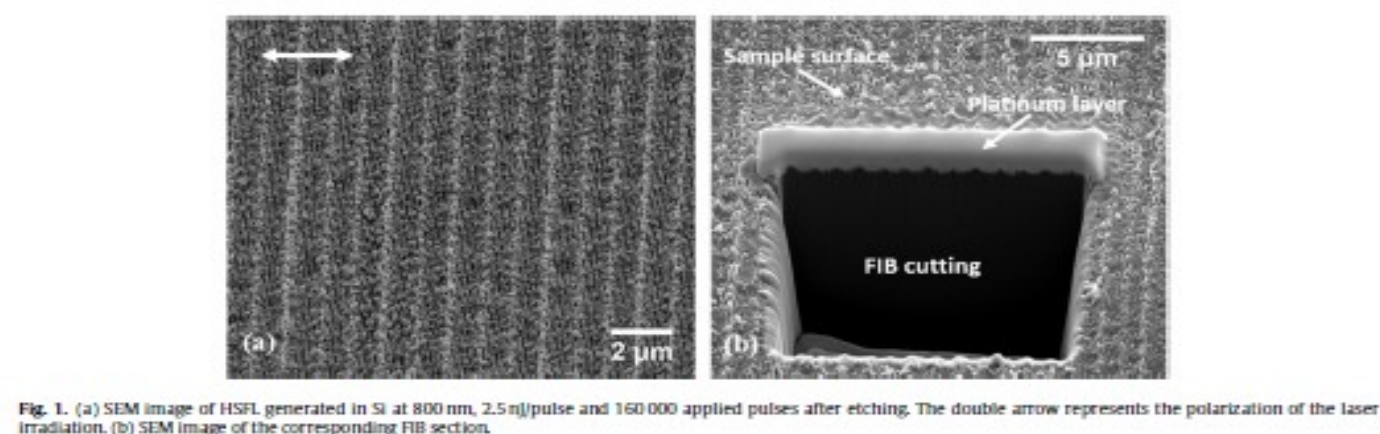

Figure 4: SEM images Femtosecond laser periodic high spatial frequency ripples using a fs laser. Re-printed from [68].

It is generally accepted that the more hydrophobic a surface is, the more rapidly a biofilm will attach. However, evidence suggests hydrophobicity is an important factor during initial attachment but may be not so during maturation stages as biofilms have been seen to continually grow, despite the reduction in surface hydrophobicity. Therefore it is critical for surfaces to be modified for the prevention of bacterial attachment at the very beginning. Laser ablation processing makes it possible to produce lateral structures reaching down to the sub-micrometer and even nano-meter scale range. One study evaluated bacterial retention on superhydrophobic titanium surfaces which had been fabricated by femtosecond laser ablation. The nanostructured titanium substrates were produced by laser ablation in liquid and the nanopillar structures were shown to prevent the attachment of Stapholococcus aureus [66]. This was in agreement with Chebolu et al. [69] who also showed that micro-patterning of poly(dimethylsiloxane) (PDMS), using a $\mathrm{CO}_{2}$ laser, had the potential to produce anti-bacterial surfaces when considering common Escherichia coli. In contrast, the work of Hasan et al. [70] showed that laser surface treatment of titanium gave rise to an enhanced $S$. aureus and Pseudomonas aeruginosa highlighting that Nd:YAG laser surface treatment, following a pre-heat treatment, could enable the selective growth of these bacteria on titanium. The contrasting reports can be explained by the complexicity of bacterial adhesion, i.e. different bacterial species respond to surfaces differently. Due to its unique specific properties, laser surface treatment provides a key technique in the fight to 
produce an antifouling surface for a wide application of surfaces. Laser modification of surfaces for the prevention of bacterial attachment could provide a high value technique for producing nanostructured surfaces with superhydrophobicity which could prevent or control the attachment of bacteria to polymeric biomaterials and other important surfaces.

For the production of thin film materials, pulsed laser deposition has been widely implemented [71-73] with excimer lasers been somewhat the most common laser to conduct pulsed laser deposition [73]. Excimer lasers have been more commonly implemented for this technique as the absorption coefficient of materials increases at shorter laser wavelengths and is a major benefit as it allows greater control of the deposited layer thickness [73]. With specific regard to polymeric materials smooth thin films of poly(methyl methacrylate) (PMMA) can be produced using relatively high energy densities [71] and by using these high energy densities, the chemical structure can be modulated [71, 72]. The work of Cristescu et al. [72] compared pulsed laser deposition with matrix-assisted pulsed laser evaporation (MAPLE), and concluded that pulsed laser deposition of pullulan (a polymeric biomaterial) could not be used with this technique as resulting thin films had a different composition. Furthermore, they also concluded that the MAPLE technique was more viable for this specific polymeric biomaterial. From this, it can then be seen that pulsed laser deposition does not seem to be the most optimum technique to produce polymeric biomaterials to modulate the wettability characteristics resulting in improved bioactivity. However, with more research this technique may be able to give rise to a chemical composition which allows for a more favourable biological and microbiological adhesion response.

In a study by Huang et al. [74], it was found that ZnO-PEG deposited by the MAPLE process significantly prevented silicone hydrogel substrates from both protein fouling and bacterial contamination. Also, they found the MAPLE technique to be efficient in producing a homogeneous deposit on the surface of silicone which does not influence the polymer (PEG) structure. The MAPLE technique has proven to be successful in applying protein-resistant coating to surfaces in order to prevent the adsorption of proteins to the surface, which is known to facilitate microbial attachment and subsequent biofilm formation [75]. It should also be noted that the MAPLE is a non-contact technique which therefore eliminates a major source of contamination and can be integrated with other sterile processes [74].

Laser surface treatments have been shown to widely promote the manipulation of surface chemistry and this can give rise to a variation in the wetting and adhesion characteristics of a material [4, 56, 59, 76-79]. From a biological point of view, laser processing of materials in air gives rise to an increased generation of surface oxygen content and this can be seen of benefit for biomaterials as an increase in surface oxygen could lead to the formation of oxidized functional groups. With this in mind, laser surface processing in different ambient gases can be used to generate surfaces with differing surface chemistry composition. Niino and Yabe [80] UV laser processed polytetrafluoroethylene (PTFE) in a hydrazine vapour 
which resulted in a change in surface chemistry, consequently increasing the adhesion properties. Following on, Pfleging et al [52] compared the processing of polystyrene surfaces using three different processing gases (air, $\mathrm{O}_{2}$ and $\mathrm{He}$ ). This enabled them to modify the surface chemistry of polymeric biomaterials and show that this can elicit changes in the wettability characteristics and biological adhesion.

\subsection{Lithography}

Lithography can take different forms, including: photolithography; X-ray lithography; extreme- ultraviolet lithography; atomic force microscopic (AFM) lithography; electron beam direct-write lithography; chargedparticle lithography; neutral-particle lithography; nanoimprint lithography; step flash and imprint lithography; dip-pen lithography; magnetolithography; and computational lithography. With the development of nanotechnology and the interest in how nano-surface engineering affects the wettability characteristics of a material considerable research interest has been observed [50, 81-84]. For instance, lithography is used in the nano-electronics industry in the fabrication of nano-circuitry and nano-electromechanical systems [85]. Recent investigation has shown that silicon nano-wires narrower than 22 $\mathrm{nm}$ can be created using electron beam lithography in conjunction with diluted hydrogen silsesquioxane (HSQ) [86]. An example of the typical surface structures which can be produced using nano-imprint lithography and metal-catalyzed electroless etching can be seen in Figure 5.

Photolithography or optical lithography is the main form of nanolithography. It can produce precise, small (few tens of a nanometre) patterns on a surface in a cost-effective manner. What is more, it affords exact control over the shape and size of the pattern. However, this method of surface treatment requires a completely flat substrate to start with and therefore pre-processing may be required in order to acquire this flat substrate. Therefore, this method is not very effective at creating nonflat topographical patterns on the surface of a material. Extremely clean operating conditions are also necessary for this method of surface treatment, making it sometimes inaccessible to industry due to logistics and high cost.

Aside from biotechnology, nano-imprint lithography has been used in optics, photonics, and electrical applications. This is due to its ability to effectively pattern various polymers [87]. It also plays a huge part in the micro and nano-technology industries, as the resolution that it can achieve is improving continuously. Its role is fundamental in the semiconductor industry, creating ever smaller electrical components and achieving higher density integrated circuits (ICs) [88]. This method of surface treatment also plays a vital role in the manufacture of antireflective structures and polarisers [89]. Nano-imprint lithography has also recently been used to alter the topographic patterns on a filtration material for water, reducing the effect of colloidal deposition or membrane fouling. Furthermore, it has been seen that this method reduces the effects of membrane fouling [90]. 


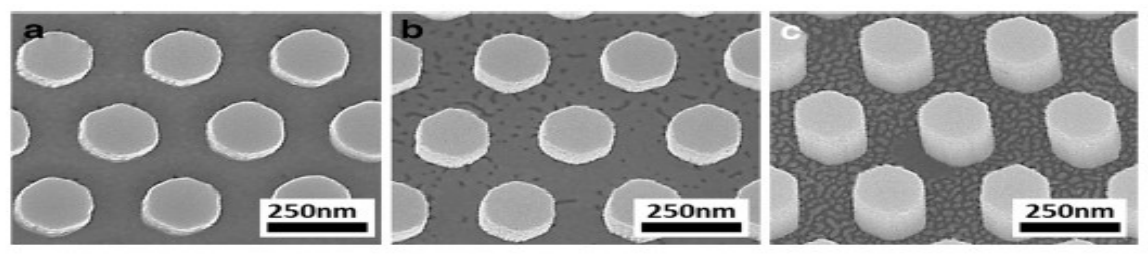

Figure 6 Plan view SEM images of Si nanostructures after different etch durations with the NIL masks removed. (a) 30-, (b) 60-, and (c) 180-5 etch durations. The top surfaces of the nanostructures remain smooth after the process due to a good degree of protection offered by the NIL. masking ayer. This contrasts with the rougher sidewalls. Slight narrowing in the lateral dimensions of the Si nanostructures from approximately $180 \mathrm{~nm}$ to pprox mately $160 \mathrm{~nm}$ occurs when the etching duration is increased from 30 to $180 \mathrm{~s}$. The fine lines or streaks observed in (b) and to a greater degre in (c) between the Si nanostructures are attributable to non-uniform gold coating of low-relief surfaces between higher structures prior to FESEM to

Figure 5: Silicon nano-structures formed using nano-imprint lithography and metal-catalyzed electroless etching at etch durations of (a) $30 \mathrm{~s}$, (b) $60 \mathrm{~s}$ and (c) $180 \mathrm{~s}$. Re-printed from [91]

Lithography has been featured numerous times as a technique to manipulate biological adhesion [92-99]. For instance, Biggs et al. [100] showed that it was possible to regulate the osteoblast cell adhesion for orthopedic prosthesis by creating a nano-pit array on a polycarbonate (PC) surface. Furthermore, it was found that highly ordered nano-pit arrays perturbed cellular adhesion by reducing cell interaction; on the other hand, disordered nano-pits enhanced cellular adhesion. This is consistent with the review conducted by McNamara et al. [101] who discussed and highlighted that stem cell differentiation can be manipulated using nanolithography. This is significant as both works show that through surface treatments cell morphology and differentiation can be accurately modulated and, with a more optimized process, it will likely one day provide clinicians and the biomedical industry with a means of producing tailored cells, tissues and even organs. What is more, through the work of Recknor et al. [102] it was possible to ascertain that photolithography has the ability to induce micro-patterns in materials for the purpose of affecting astroglial cell growth with specific regard to cell distribution and orientation. Furthermore, this research showed that the introduction of laminin on the micro-patterned substrate gave rise to an enhancement of cell orientation, elongating them further when compared to solely using the micro-patterned surface. Cell orientation and distribution, and how biological adhesion can be affected using lithography techniques, was also confirmed by Miller et al. [103]. In addition to cell adhesion modulation, it was also commented that nano-machining with lithography could be applied to cell transfection and drug delivery [93], two areas of extreme in importance within the healthcare industry.

Lithography has been applied to numerous studies for the adhesion of bacteria. This has involved using lithography in the development of micrometre-scale patterning [104-107], nanometre-scale patterning [108113] and chemical patterning [114] for the manipulation of bacterial adhesion. These tend to fall into two different categories: bacterial adhesion modulation [105, 106, 108, 109, 113-115] and bacterial capture $[104,107,111,112]$. Much of the research pertaining to bacterial adhesion modulation relates to the modification of surface properties to reduce the amount of bacterial adhesion and biofilm formation. $\mathrm{Xu}$ and Siedlecki [110] reported that staphylococcal bacterial adhesion at low 
shear stresses can be reduced as a result of sub-micrometer lithographic patterning of polyurethane. What is more, they also concluded that as bacterial attachment was reduced by this particular technique, subsequent biofilm formation was also reduced/prevented. This is reaffirmed by Singh et al. [108] who showed that lithography could be used to hinder bacterial growth and subsequent biofilm formation on nanostructured titanium oxide surfaces. Bacterial capture and guided growth requires a surface where discrete areas are modified to promote bacterial adhesion and growth in comparison to others. Krkso et al. [111] showed that lithography could be implemented to control bacterial adhesion by surface patterning of poly(ethylene glycol) (PEG) hydrogels. This research has been taken further to provide the scientific community with methods to immobilize single bacterial cells so that biosensors and single cell studies can be optimized. This is highly significant as Singh et al. [108] and Komaromy et al. [109] do state that the investigation of nano-surface-structures and their effects on bacteria can be used to gain a deeper understanding of bacteria-surface interactions. This is a very interesting point as a better understanding of bacteria-surface interactions will lead to the development of tailor-made surfaces to manipulate bacterial adhesion and growth.

\subsection{Micro/Nano Contact Printing}

Owing to the expansion and growth of biological and microbiological industries, the focus, over the last ten to twenty years, has moved to producing surfaces efficiently and at a low cost to keep income revenues high. As a direct result of this, the interest in adopting polymeric materials, which are seen by industry as a cost-effective alternative to other material types, has increased. This is on account of the fact that polymeric materials generally tend to be cheaper than metals and ceramics and can be seen in many instances to be easier to machine and manipulate to adapt the polymer for use in specific environments, especially biological environments. To this end, micro- and nano-printing has been developed and applied to polymeric materials [116-121]. A typical surface resulting from micro-contact printing can be seen in Figure 6. Charest et al. [121] investigated the effects of hot embossing of polyimide on osteoblast cell growth and their results showed that cell growth alignment was possible with this technique. Futhermore, they suggest that hot embossing is an attractive technique for scale-up manufacturing. This is an interesting point as the technique is costeffective and is relatively easy to scale-up. Having said this, it is well known that there can be issues with this type of technology in terms of repeatability, especially when working in the nano-meter surface topographical regimes. One attractive aspect of micro/nano printing of polymers is that of introducing both topographical and surface chemistry changes into the material. This is evidenced by Ruiz et al. [116] and Dusseiller et al. [120] who showed that neural cell growth and epithelial cell growth can be manipulated with this technique, respectively. This technique has been advanced further by using proteins in the micro/nano 
contact printing [117-119] which allows for a more bio-functionalized surface to be developed.
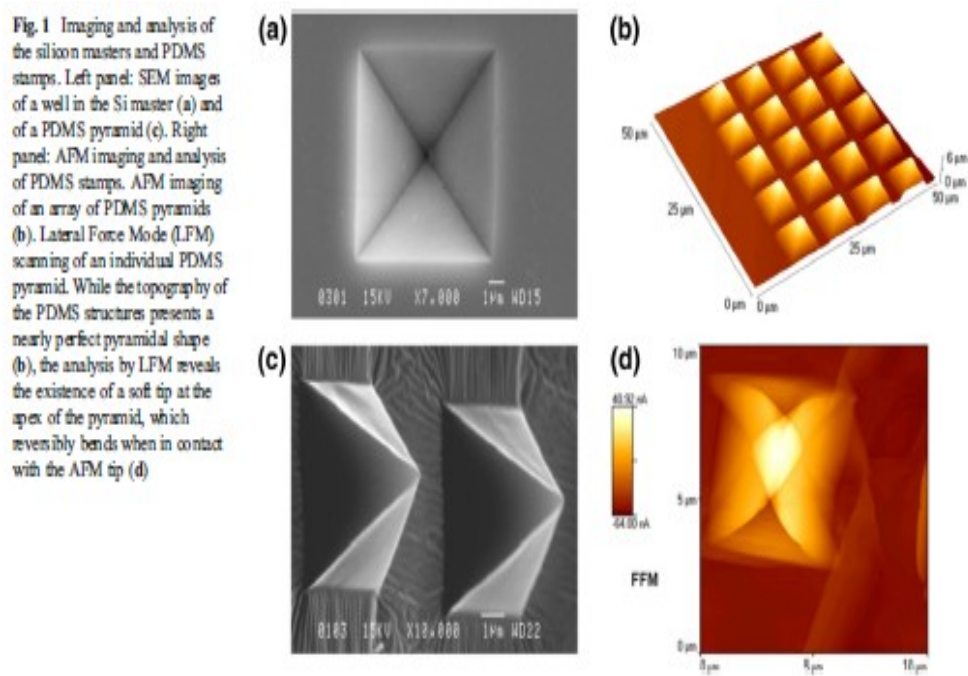

Figure 6: A typical example of micro-contact printing to produce pyramidal shapes for use in protein patterning. Re-printed from [122]

A very interesting development in bioengineering, in recent years, is that of bioprinting [115, 123, 124]. In 2009, Xu et al. [115] highlighted how bioprinting could be implemented to achieve large-scale manufacturing production of biosensors. Leading on from this, Catros et al. [123] took bioprinting further by showing how the technique can be used to create patterns of nano-hydroxyapatite and human osteoprogenitors on material surfaces to enhance cell growth and to manipulate cell growth parameters such as cell proliferation and differentiation. This has been further confirmed by Tasoglu and Demirci [124] who showed that bioprinting could be applied to stem cell research as a method to control viable stem cell growth, proliferation and differentiation. This is a significant advancement in the field of biological adhesion as it does tend to take care of the limitations of other scaffold/substrate-based approaches in that bioprinting can give rise to the complex cell-surface and cell-cell interactions needed for the production of a viable and functional tissue.

It should be noted that there is very little in the way of effecting bacterial growth through micro/nano contact printing in the literature. Having said this, bioprinting of bacterial cells has been conducted to manipulate and control bacterial adhesion $[125,126]$. These intriguing applications of bioprinting lend themselves to applications such as biosensors and investigating bacteria cell-surface and cell-cell interactions to potentially ascertain the mechanisms for bacterial cell attachment and colonisation.

\subsection{Plasma Surface Treatment}

Plasma surface modification has the ability to modify the surface properties of a material, keeping the original bulk properties intact, and has numerous industrial applications such automotive, microelectronics and biomedical [127-129]. An example application is given in Figure 7 whereby boron nitride nano-tubes (BNNT) were plasma surface treated to 
modify the BNNT wettability and adhesion characteristics. On account of its benefits, it has extensively been shown that plasma surface treatment can give rise to an enhanced biological cell response [130-137]. Having said this, Arefi-Khonsari et al. [138] showed that certain polymers such as octadecyltrichlorosilane self-assembled monolayers (OTS-SAM) are much more resistant to this technique compared to polyethylene (PE), indicating that the successful implementation of this particular technique is material dependent. Even though this may be the case, Milde et al. [139] reported that the adhesion property of PVD coatings could be enhanced through ECR plasma treatment. The enhancement of adhesion property of polyimide and fluorinated ethylene propylene (FEP), using electron cyclotron resonance (ECR) plasma treatments, was also highlighted by Abdul Majeed et al. [140]. They also inferred that the surface chemistry and wettability characteristics of a material could be significantly altered through exposure to atomic oxygen ions. On account of the large variations in wettability characteristics which this technique can elicit, a large amount of investigations have been carried out in to how plasma surface treatment can modulate the adhesion characteristics of materials [137, 141-143]. An interesting and important hypothesis came from the work of Lai et al. [142] who concluded that the $\mathrm{C}=\mathrm{O}$ double bond ratio was an important driver for $\theta$ and the wettability characteristics of polymeric surfaces. This is of major interest as it does suggest that the bond ratio could have implications in the adhesion characteristics of the material and may need to be investigated in relation to biological and microbiological adhesion.

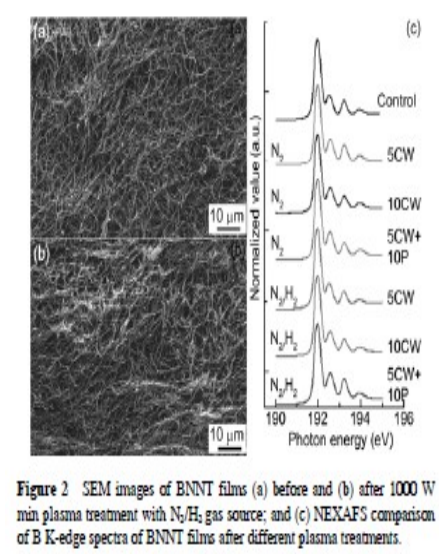

Figure 7: SEM images of (a) as-received and (b) plasma surface treated boron nitride nanotubes. Re-printed from [144]

It has been shown that it is possible to utilize these induced surface modifications for numerous biomaterials. Chu and coworkers [145-147] have undertaken an extensive amount of research into this field and have shown that it is possible to use plasma based surface modification to enhance the bioactivity of diamond-like carbon. From research such as this, it is possible to foresee that plasma-based technologies could potentially be used for polymeric biomaterials in order to improve upon their bioactivity for use in biological environments. Plasma surface 
treatments have also been extensively used in the production of surfaces to control and investigate bacterial adhesion on numerous material types [148-155]. Plasma immersion ion implantation has been applied to surface treat poly(vinyl chloride) (PVC) [153] to successfully improve the antibacterial properties with specific regard to Staphylococcus aureus and E. coli. This has been further evidenced with Staphylococcus aureus and Staphylococcus epidermis on plasma-treated poly(ethylene terephthalate) (PET) [150, 155], E. coli on plasma-treated polyurethane (PU) [152] and Pseudomonas aeruginosa on plasma-treated) PVC [151]. All of which showed a reduction in the adhesion of bacteria to the respective surfaces. Having said this, it has been observed that the modified surface properties deteriorate just over a week [153] which has implications in applying this technology to the microbiological industry. What is more, even after some of the techniques show an increase in antibacterial activity of up to $50 \%$, in many cases this was not enough to eradicate bacterial colonization [151] and, ultimately, requires further investigation to bring about this eradication using plasma-based technologies.

\subsection{Radiation Grafting}

This technique has been employed within the biomaterials industry and enables one to selectively place chemical molecules onto a material surface to improve the cell adhesion [156]. This has also been confirmed by Mao et al [157] who showed that radiation grafting of $O$-butyrylchitosan onto nylon films enhanced the biofunctionality of the nylon, providing a suitable means for tailoring nylon for specific biological applications. In addition to the benefit of giving rise to increased biofunctionality, radiation grafting is a very clean method [20] and allows for indirect, costeffective sterilization of biomaterials [156]. In addition, uniform nanometre layers can be modified through radiation grafting with a source of $172 \mathrm{~nm}$ UV light and this gives rise to surface durability enhancement [158] of materials which can be implemented as load bearing components [156].

Laser-induced grafting is another variation of radiation grafting and is an efficient means of manipulating the surface chemistry of a material, allowing additives to be placed on or embedded into a material surface [55]. This techniques promotes the formation of radicals which leads to chemical reactions, subsequently modifying the surface chemistry. Charbonnier et al. [159] used laser grafting of nitrogen atoms onto the surface of polycarbonate to show that, by increasing the laser fluence, the grafting of nitrogen onto the polycarbonate surface could be increased. Most of the investigations on $\mathrm{CO}_{2}$ laser grafting have been conducted by Mirzadeh and coworkers $[21,159,160]$. In their work they performed investigations of grafting 2-hydroxyethyl methacrylate (HEMA), N-vinyl-2pyrrolidone (NVP), acrylamide (AAm) onto ethylene-propylene rubber (EPR). These investigations showed that $\mathrm{CO}_{2}$ laser grafting gave rise to an enhancement of biological cell adhesion, although it was evidenced that the process of cell spreading was highly dependent on the amount of hydrophilic chains grafted onto the samples [21]. In addition, they carried 
out in vivo studies to AAm and HEMA grafted EPR, showing that $\mathrm{CO}_{2}$ laser grafting can be employed to enhance the bioactivity of EPR [160].

Radiation grafting has been applied for the development of surfaces for the scientific study and control of bacterial adhesion and growth [34, 161166]. The works of Terada and coworkers [161, 162] showed how grafting diethlamine (DEA), ethylamino (EA) and sodium sulphite (SS) onto polymeric surfaces can manipulate bacterial adhesion and viability. This work allows one to realise that the electrostatic charge of the materials they were grafting had a large influence on the bacterial adhesion. This leads one to realizing the potential of electrostatic interactions and how they could be implemented to modulate bacterial adhesion. Furthermore, they state that bacterial cell wall structures are likely to very much affect the viability [162] and this should be accounted for in future studies which are likely to investigate bacterial cell-substrate interactions. Whilst Terada and coworkers [161, 162] showed that radiation grafting gave rise to an increase in bacterial adhesion, this is contrasted by Nava-Ortiz et al [164] who showed that Candida albicans adhesion can be reduced, preventing the formation of a biofilm on polyethylene (PE) and polypropylene (PP). It should be noted that Candida albicans is a fungus which, although forms a biofilm, has a very different adhesion and growth mechanism when compared to other forms of bacteria. Having said this, this is still of significant interest for the biomedical device industry as this research has shown that radiation grafting can provide a means of promoting the adsorption of albumin and reducing the adsorption of fibrinogen, producing a more enhanced biocompatible polymeric material. It should also be noted that radiation grafting can be used for the capture and immobilization of bacterial cells $[163,165]$. This is significant as, like with lithography, this technology could be implemented for applications such as biosensors and single bacterial cell analysis.

\subsection{Ion Beam and Electron Beam Processing}

Ion beam processing is another surface treatment technique for biological applications which enables the production of surface layers, with the required material properties, having a negligible effects on the bulk properties [19, 167]. An example of a typical surface arising from ion beam and electron beam processing is given in Figure 8. One variation of ion beam processing, ion implantation [167], injects ions into the material with energies which range from $10^{1}$ and $10^{6} \mathrm{eV}$. This modifies the surface properties and has been applied to enhancement of fatigue and wear, modulation of lubricity, increasing toughness, improving corrosion, modulation of conductivity and modulating bioreaction properties [19]. Some of the major advantages of this technique are that enables discrete and selective processing of materials and large area processing is a possibility [167], an aspect which would be very appealing to industry. Having said this, the initial costs and running costs for such a technique can be high in comparison to competing surface treatment techniques. Furthermore, the processing depths in which modification can occur are small and could have implications with regards to the robustness of the developed surface. 

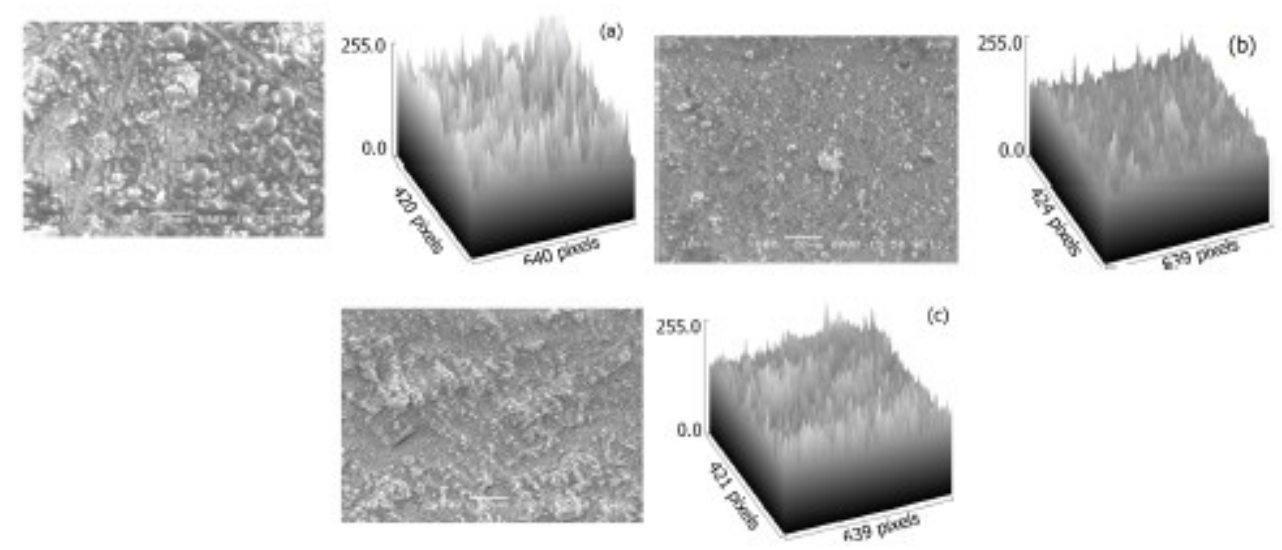

Figure 8: Typical effects on surface topography following ion beam and electron beam processing.. Re-printed from [168].

Cho et al. [169] employed ion assisted reactions (IAR) to modify the surface of polymeric materials to manipulate the wettability characteristics, enhancing their hydrophilic nature. In addition, Aubry et al. [170], used a focused ion beam (FIB) to generate surface topographies that had a high enough resolution for applications in diffractive optical elements (DOEs). Furthermore, through the application of FIB, it has been shown that ripple patterns can be formed on polymeric materials (see Figure 9), a surface similar to that seen with the application of femtosecond laser processing (see Figure 4). This research highlighted the potential of this technology to produce surfaces with topographies that could manipulate biological and microbiological adhesion. With this in mind, it has been seen that heavy ion grafting can be employed to enhance the bioactivity and biofunctionality of polymeric biomaterials by increasing the adsorprtion of proteins with the aim to increase the absorption of biological proteins [167]. Ion beam assisted deposition (IBAD) has mainly been implemented for the production of hydroxyapatite coatings and diamond-like carbon (DLC) film [19]. Ion beam texturing (IBT) has also given rise to the generation of micrometre-scale and nanometrescale features on materials for in vivo applications [19]. 

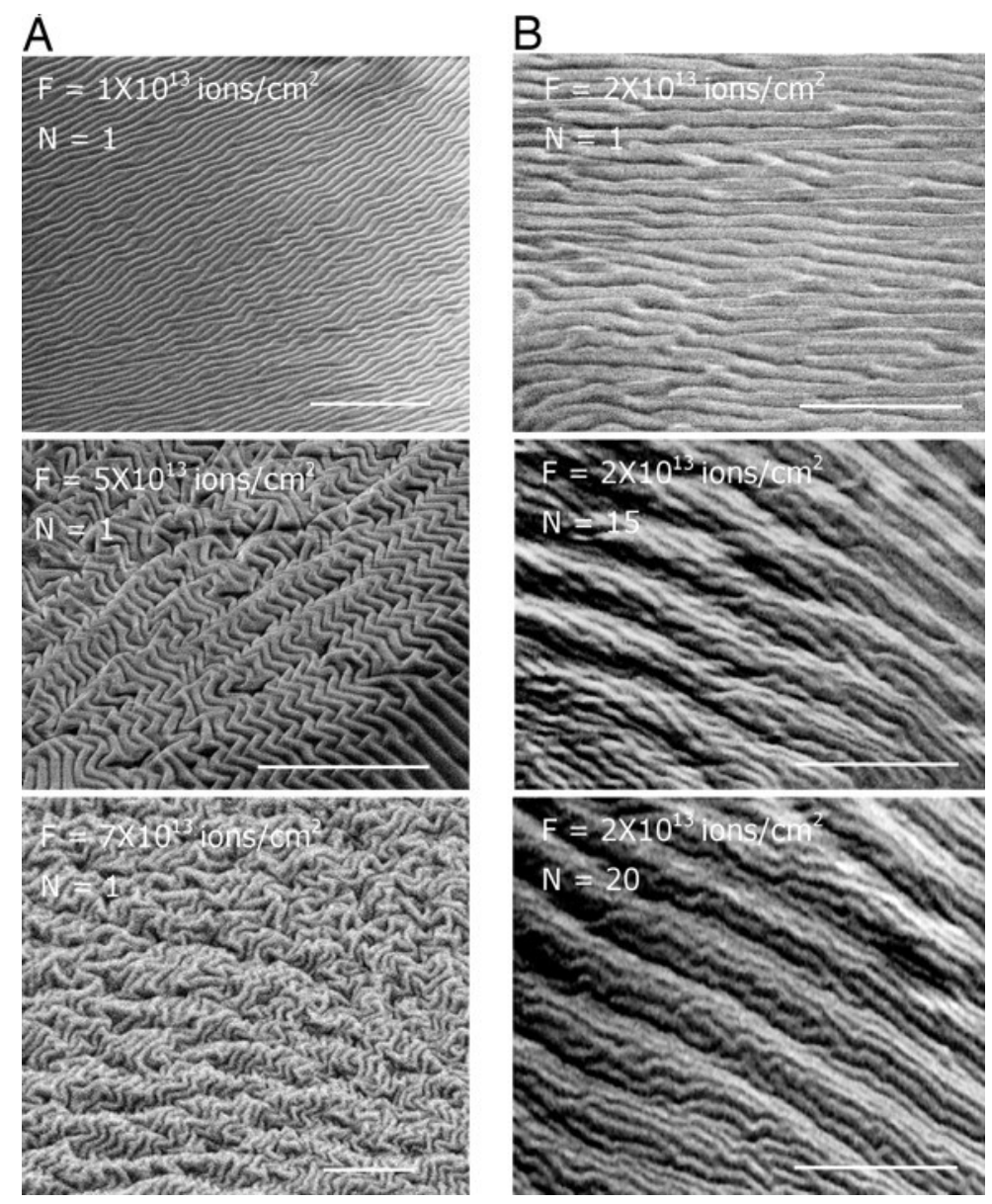

Figure 9: Focused ion beam producing wrinkle patterns on polymer surfaces. Re-printed from [171] Copyright (2007) National Academy of Sciences, U.S.A.

Like ion beam processing, electron beam (EB) processing has also been used for the manipulation of surface properties. For instance, Iwanaga et al [172] showed that EB polymerization for grafting polyacrylamide onto tissue culture polystyrene (TCPS) gave rise to an enhancement in biological adhesion, increasing cell adhesion and proliferation. This ultimately indicates that EB processing can be used in applications such as biosensors and tissue engineering devices.

Ion beam technology has also been employed to produce various topographies and surface chemistries, mainly through the use of ion beam sputtering [173-175] but ion beam etching has also been effectively employed [176]. Trujillo et al. [173] have shown that ion beam sputtered silver-doped hydroxyapatite on titanium can have the advantage of hindering Staphylococcus epidermis and Pseudomonas aeruginosa growth. Having said this, they also correctly state that these surfaces are not fully stable and as a result require further investigation. Ion sputtering technologies have also been implemented for the capture and immobilization of bacterial cells, as shown in the research conducted by Whitehead et al. [174, 175]. This research on the capture and immobilization of bacterial cells has shown how micrometre-scale features on silicon and titanium can give rise to controlled bacterial adhesion and 
growth in specific, discrete areas. Little work has been conducted with the application of ion beam etching to hindering microbiological adhesion; however, the work of Ivanova et al. [176] has developed black silicon using this particular technique. This is of current extreme interest as black silicon is a material which consists of nano-scale features and has been shown to exhibit a high antibacterial effect based solely on surface topography and independent of surface chemistry composition. The surface of the black silicon developed by Ivanova et al. [176] can be visualised in Figure 10, showing the formation of sub-micrometer to nanometer structures on polymer surfaces.
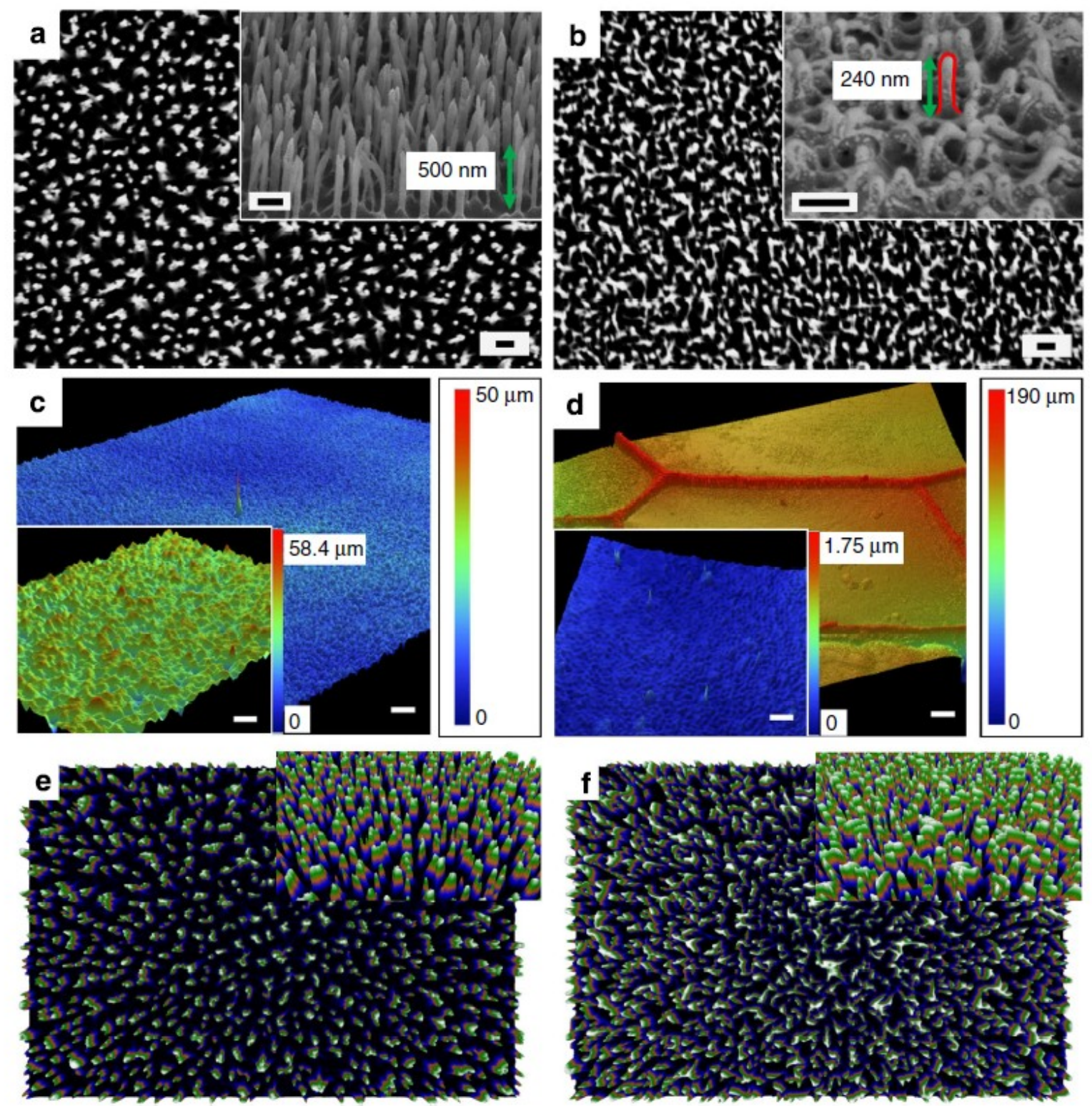

Figure 10: Typical SEM images and surface profilometry of black silicon using reactive-ion beam etching. Re-printed from [176].

There has also been little work conducted in the application of electron beam surface engineering to microbial attachment. Krsko et al. [177] considered neuronal cells and employed electron beam technologies to 
surface pattern poly(ethylene glycol) hydrogels to discriminate between eukaryotic cells and bacterial cells. This is highly significant as it shows that these technologies can be used to aid in the differentiation between different cell types which tend to have very different properties such as adhesion mechanisms and cell sizes. The results presented by Pucket et al. [178] show that the adhesion of Staphylococcus aureus, Staphylococcus epidermis and Pseudomonas aeruginosa, through the nanostructuring of titanium with electron beam processing, can be significantly reduced. This is highly significant as Staphylococcus aureus, Staphylococcus epidermis and Pseudomonas aeruginosa are all known bacterial cells which give rise to implications in orthopaedic implants. One can then see that by the further application of the work conducted by Krsko et al. [177] the adhesion and growth of these bacterial cells can be reduced through the patterning of materials using electron beam technologies.

\subsection{Prospects}

Although much research has been carried out on evaluating eukaryotic cell response, comparatively, limited research has been carried out in regards to establishing the response of bacterial cells to nano-topography and the literature that has been published in this field reports conflicting findings, with some researchers finding a greater level of attachment to nano-phase surfaces than to conventional surfaces, while others found a repellent effect of nano-phase materials to bacterial cells [17]. Whilst these surfaces are known to be effective, they are subject to many limitations. For example, if the modified surface has been produced using a chemical antibacterial mechanism, the pharmacodynamics and kinetics need to be thoroughly evaluated. Complex chemical surface modifications need to be carefully designed and carried out as the resulting functionalised surface may undergo further reactions which may adversely affect their bactericidal properties [43]. For bioactive surfaces, it is possible for bacteria to develop resistance against the active agent and it can also take a long time for the release of antibacterial agents from the surface. With bioactive surfaces, it is also possible that the durability of target substrate may not be sufficient to maintain long-term antibacterial property [179].

Table 1 summarises the main technical aspects for each of the surface treatments discussed within this review. This provides the main materials that can be processed, the typical smallest feature size that one would currently expect, the advantages and disadvantages for each of the surface treatments. It should be noted, though, that throughout the literature these technical aspects are widely discussed. However, it has been highly apparent that there is a lack of discussion and evidence in the literature with regards to the longevity of induced surface treatments and the likely degradation of the surfaces overtime with respect to modulating bioadhesion. Taking ion beam and electron beam processing, as an example, the surface processing depths are comparatively low meaning that the induced surface modifications will, at most be a few micrometers deep. To date, there is not a wide ranging discussion in the research which 
contends with the effects of considerations such as wear, fatigue and hydrophobic recovery on the modified surface parameters which give rise to modulated bioadhesion. As a result of this, it would be highly beneficial to consider this aspect when conducting research into surface treatments to modulate bioadhesion. This is a highly significant aspect which is currently being overlooked by researchers but would likely need to be significantly considered and tested before a surface treatment could be implemented in a commercial setting.

Table 1: Summary of the technical aspects for each surface treatment that can be implemented for bioadhesion modulation. Note: $\mu m=$ micrometer;

\begin{tabular}{|c|c|c|c|c|}
\hline Process & $\begin{array}{l}\text { Materi } \\
\text { als }\end{array}$ & $\begin{array}{l}\text { Typical } \\
\text { Smalles } \\
\text { t } \\
\text { Feature } \\
\text { Size }\end{array}$ & Advantages & Disadvantages \\
\hline $\begin{array}{l}\text { Laser } \\
\text { Surface } \\
\text { Treatme } \\
\text { nt }\end{array}$ & $\begin{array}{l}\text { Cerami } \\
\text { cs; } \\
\text { metals; } \\
\text { polyme } \\
\text { rs. }\end{array}$ & $\begin{array}{l}\text { Mainly } \\
\mu \mathrm{m} \text { but } \\
\text { sub- } \mu \mathrm{m} \\
\text { and } \mathrm{nm} \\
\text { possible. }\end{array}$ & $\begin{array}{l}\text { Flexibility; } \\
\text { ease of scale } \\
\text { up; non- } \\
\text { contact; } \\
\text { accuracy and } \\
\text { repeatability; } \\
\text { can modify } \\
\text { the surface } \\
\text { topography } \\
\text { and } \\
\text { chemistry, } \\
\text { simultaneousl } \\
\text { y. }\end{array}$ & $\begin{array}{l}\text { Reflective } \\
\text { materials } \\
\text { difficult to } \\
\text { process; non- } \\
\text { homogenous } \\
\text { energy } \\
\text { distribution; } \\
\text { wavelength/mat } \\
\text { erial absorption } \\
\text { dependency. }\end{array}$ \\
\hline $\begin{array}{l}\text { Lithogr } \\
\text { aphy }\end{array}$ & $\begin{array}{l}\text { Mainly } \\
\text { polyme } \\
\text { rs. }\end{array}$ & $\begin{array}{l}\text { Mainly } \\
\text { sub- } \mu \mathrm{m} \\
\text { and } \mathrm{nm} \text {. }\end{array}$ & $\begin{array}{l}\text { Fast } \\
\text { processing } \\
\text { times; can be } \\
\text { cost-effective; } \\
\text { well-proven } \\
\text { technology. }\end{array}$ & $\begin{array}{l}\text { Equipment set- } \\
\text { up can be } \\
\text { complex; } \\
\text { requires a } \\
\text { completely flat } \\
\text { substrate } \\
\text { initially; } \\
\text { extremely clean } \\
\text { operating } \\
\text { conditions }\end{array}$ \\
\hline
\end{tabular}




\begin{tabular}{|c|c|c|c|c|}
\hline & & & & needed \\
\hline $\begin{array}{l}\text { Micro/N } \\
\text { ano } \\
\text { Contact } \\
\text { Printing }\end{array}$ & $\begin{array}{l}\text { Mainly } \\
\text { polyme } \\
\text { rs }\end{array}$ & 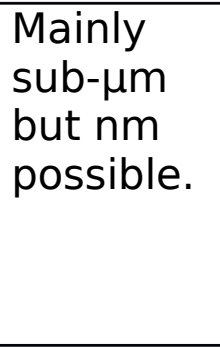 & $\begin{array}{l}\text { Low initial } \\
\text { capital costs; } \\
\text { high } \\
\text { repeatability } \\
\text { at } \mu \text { m and } \\
\text { most sub- } \mu \text { m } \\
\text { techniques. }\end{array}$ & $\begin{array}{l}\text { Limited } \\
\text { precision and } \\
\text { repeatability } \\
\text { with some sub- } \\
\mu \mathrm{m} \text { and nm } \\
\text { techniques. }\end{array}$ \\
\hline $\begin{array}{l}\text { Plasma } \\
\text { Treatme } \\
\text { nt }\end{array}$ & $\begin{array}{l}\text { Cerami } \\
\text { cs, } \\
\text { metals, } \\
\text { polyme } \\
\text { rs. }\end{array}$ & $\begin{array}{l}\text { Mainly } \\
\mu m \text { but } \\
\text { sub- } \mu m \\
\text { possible. }\end{array}$ & $\begin{array}{l}\text { Easily } \\
\text { combines } \\
\text { chemical and } \\
\text { physical } \\
\text { modification, }\end{array}$ & $\begin{array}{l}\text { Treats small } \\
\text { surface areas } \\
\text { which can lead } \\
\text { to long } \\
\text { processing } \\
\text { times; complex } \\
\text { equipment set- } \\
\text { up; high initial } \\
\text { capital costs. }\end{array}$ \\
\hline $\begin{array}{l}\text { Radiati } \\
\text { on } \\
\text { Graftin } \\
\text { g }\end{array}$ & $\begin{array}{l}\text { Mainly } \\
\text { polyme } \\
\text { rs }\end{array}$ & $\begin{array}{l}\text { Induces } \\
\text { chemical } \\
\text { modificat } \\
\text { ion on } \\
\text { the } \mu \mathrm{m} \\
\text { scale. }\end{array}$ & $\begin{array}{l}\text { Well } \\
\text { established; } \\
\text { can induce } \\
\text { surface } \\
\text { chemistry } \\
\text { changes with } \\
\text { minimal } \\
\text { effect to } \\
\text { surface } \\
\text { topography. }\end{array}$ & $\begin{array}{l}\text { Lack of accuracy } \\
\text { leading to a risk } \\
\text { of unwanted } \\
\text { areas of } \\
\text { modification; } \\
\text { running costs } \\
\text { can be high. }\end{array}$ \\
\hline $\begin{array}{l}\text { Ion } \\
\text { Beam } \\
\text { and } \\
\text { Electro } \\
\text { n Beam } \\
\text { Process } \\
\text { ing } \\
\end{array}$ & $\begin{array}{l}\text { Cerami } \\
\text { cs; } \\
\text { metals; } \\
\text { polyme } \\
\text { rs }\end{array}$ & $\begin{array}{l}\text { Mainly } \\
\text { sub- } \mu \mathrm{m} \\
\text { but nm } \\
\text { achievab } \\
\text { le. }\end{array}$ & $\begin{array}{l}\text { Highly } \\
\text { selective and } \\
\text { accurate } \\
\text { processing; } \\
\text { repeatability; } \\
\text { potential for } \\
\text { scaling-up. }\end{array}$ & $\begin{array}{l}\text { Processing } \\
\text { depths are } \\
\text { small; initial and } \\
\text { running costs } \\
\text { are high. }\end{array}$ \\
\hline
\end{tabular}

Table 2 summarises and quantifies the industrial/commercial parameters of the techniques discussed in this review. As one can see, lithography has the largest total score and this is derived from high flexibility, high accuracy and high potential for scaling up to industrial manufacture, in spite of the relative high initial capital cost required. This is also reflected by the many journal papers which have been reviewed. Having said this, for manufacturing and scaling up many bioengineering companies may consider the initial capital cost and potential for scaling up as the most important factors and on account of them requiring high-throughput at a low initial investment. With this in mind, laser surface engineering would offer slightly better prospects; however, issues with flexibility including potential issues with laser absorption with some materials may cause a company to look at other competing techniques. It should be noted that 
the lowest total scores were derived from plasma surface treatment, radiation grafting, ion beam processing and electron beam processing. Although, it should be noted that they are only the lowest by two to three points and this is mainly due to the prospects of these technologies for automation and scaling up for industrial-scale manufacturing. Therefore, due to the close total scores, it is important to realize that the choice of technique is highly likely going to be due to the application. That is, the surface engineering technologies to modulate biological adhesion and microbiological adhesion are likely going to be decided upon based on their abilities to create and promote micro-metre scale features, nanoscale features and/or surface chemistry modification on specific material types. Furthermore, it should be noted that a more in-depth business study of each technique is required to fully understand the economic and technical implications of industrial take-up. Such a study would be of extreme interest to those companies which are currently undertaking surface treatments or are wanting to invest in surface treatment technologies to develop their products/services.

Table 2: Matrix quantifying the industrial/commercial parameters of surface engineering techniques which can be used for the manipulation of biological and microbiological adhesion.

\begin{tabular}{|c|c|c|c|c|c|c|c|}
\hline & $\begin{array}{c}\text { Ca } \\
\text { pit } \\
\text { al } \\
\text { Co } \\
\text { st } \\
\text { Ver } \\
\text { y } \\
\text { hig } \\
\text { h } 1 \\
\ldots \\
5 \\
\text { Ver } \\
\text { y } \\
\text { Lo } \\
\text { w }\end{array}$ & $\begin{array}{c}\text { Runni } \\
\text { ng } \\
\text { Costs } \\
\text { Very } \\
\text { High } \\
1 \ldots \\
5 \\
\text { Very } \\
\text { Low }\end{array}$ & $\begin{array}{c}\text { Ease } \\
\text { of } \\
\text { Imple } \\
\text { ment } \\
\text { ation } \\
\text { Very } \\
\text { low } 1 \\
\ldots 5 \\
\text { Very } \\
\text { High }\end{array}$ & $\begin{array}{c}\text { Flexi } \\
\text { bility } \\
\text { Very } \\
\text { poor } \\
1 \ldots \\
5 \\
\text { Very } \\
\text { Good }\end{array}$ & $\begin{array}{c}\text { Accur } \\
\text { acy } \\
\text { Very } \\
\text { poor } \\
1 \ldots \\
5 \\
\text { Very } \\
\text { Good }\end{array}$ & $\begin{array}{c}\text { Poten } \\
\text { tial } \\
\text { for } \\
\text { Scali } \\
\text { ng } \\
\text { Up } \\
\text { Very } \\
\text { low } 1 \\
\ldots 5 \\
\text { Very } \\
\text { High }\end{array}$ & $\begin{array}{c}\text { Total } \\
\text { Score } \\
\text { (out } \\
\text { of } \\
30 \text { ) }\end{array}$ \\
\hline $\begin{array}{c}\text { Laser } \\
\text { Surface } \\
\text { Engineeri } \\
\text { ng } \\
\end{array}$ & 3.0 & 3.0 & 3.5 & 3.5 & 4.0 & 4.5 & 21.5 \\
\hline $\begin{array}{c}\text { Lithograp } \\
\text { hy }\end{array}$ & 2.5 & 3.0 & 3.5 & 4.5 & 4.0 & 4.0 & 22.0 \\
\hline $\begin{array}{c}\text { Plasma } \\
\text { Surface } \\
\text { Treatmen } \\
\text { t }\end{array}$ & 2.5 & 3.0 & 3.5 & 3.5 & 3.5 & 3.0 & 19.0 \\
\hline $\begin{array}{c}\text { Radiation } \\
\text { Grafting }\end{array}$ & 2.0 & 3.0 & 3.0 & 3.0 & 4.0 & 3.0 & 18.0 \\
\hline
\end{tabular}




\begin{tabular}{|c|c|c|c|c|c|c|c|}
\hline $\begin{array}{c}\text { Ion Beam } \\
\text { Processin } \\
\mathrm{g}\end{array}$ & 2.0 & 2.0 & 3.5 & 3.0 & 4.5 & 4.0 & 19.0 \\
\hline $\begin{array}{c}\text { Electron } \\
\text { Beam } \\
\text { Processin } \\
\mathrm{g}\end{array}$ & 2.0 & 2.0 & 3.5 & 3.0 & 4.5 & 4.0 & 19.0 \\
\hline
\end{tabular}

One of the more prominent prospects related to surfaces treatments to effect biological and microbiological adhesion is that of determining the optimum surface properties required for manipulating adhesion and proliferation. Having said this, this is not a trivial aspect as the degree of adhesion and cell response varies from one type of cell to another. Furthermore, it varies considerably between biological and microbiological cell. For instance, taking biological cells as an example, it has been reported that osteoblasts preferentially adhere and proliferate on rough surfaces whilst fibroblasts are known to have an enhanced response on smooth surfaces $[25,26]$. Leading on from this, mesenchymal stem cells have been reported to have a significant sensitivity to surface roughness and topography $[6,27]$. It has also been shown that surface chemistry can play a significant role in the manipulation of biological cell growth [52, $137,180]$. This has also been seen with microbial cells where there are more conflicting reports between the effects of surface topography [176] and surface chemistry [161]. As many real biological environments involve a number of cell types, it may be the case that each cell type will have to be considered in turn experimentally, which in the main part is being seen in the literature. Then by concentrating on the cell types within a particular biological environment, researchers will likely have to consider the effects of the surface treatments of these cell types to ensure that a favourable cell response is elicited from each cell type. What is more, with the conflicting reports it would be highly advantageous to have a more collegiate world-wide approach to the manipulation of biological and microbiological adhesion as this would ensure that the research is considerably scrutinized and any trends can be more readily identified.

\section{Summary}

Over the past few decades, methods for the fabrication of engineered surfaces have been developed to study the response of eukaryotic and bacterial cells to surfaces in order to create surfaces with tailored chemical and topographical features in order to elicit a desired cell response. All of the techniques discussed in this review have, to certain extents, given rise to a modulation in the biological and microbiological cell adhesion and subsequently affected the cell growth. Having said this, there is considerable contradiction between some of the research and as such a more world-wide collegiate approach to understand cell-cell and cell-material interactions may be required to fully understand and determine the surface properties required to enhance and inhibit cell response. 
With an ageing world population, and many people being expected to work longer in their lifetime, there is a great need for surface treatments in the biological and bioengineering industry. This need is further compounded by the requirement for more efficient antibacterial surfaces within both the healthcare and food industries. It is highly promising to see that researchers are looking deeper into the cell-material interactions by employing surface treatment techniques for cell immobilization. This is significant as a better understanding of the many adhesion mechanisms will ultimately provide researchers, clinicians and industrialists with an improved platform upon which tailored surface treatments can be performed. This, in turn, will allow the production of more enhanced and complex surfaces which will ultimately lead to surfaces which can promote and hinder multiple cell type adhesion, dependent on the desired biological or microbiological environment. On account of this, it is vital that each technique is extensively tested both in vitro and in vivo to ensure that it is optimized for the corresponding biological and microbiological environment.

\section{References}

[1] A.S. Curtis and C.D. Wilkinson, Reactions of cells to topography. J.Biomater. Sci. Polym. Ed. 9, 1313-1329 (1998).

[2] L.F. Backakova, M. Parizek, T. Ruml and T. Svorcik, Modulation of cell adhesion, proliferation and differentiation on materials designed for body implants. Biotechnol. Adv. 29, 739-767 (2011).

[3] E.M. Harnett, J. Alderman and T. Wood, The surface energy of various biomaterials coated with adhesion molecules used in cell culture. Colloid Surf. B 55, 4970-4980 (2007).

[4] C.W. Chan, I. Hussain, D.G. Waugh, J. Lawrence and H.C. Man, Effect of Laser Treatment on the Attachment and Viability of Mesenchymal Stem Cell Responses on Shape Memory NiTi Alloy. Mater. Sci. Eng. C 42, 254263 (2014).

[5] H. Mirzadeh and M. Dadsetan, Influence of laser surface modifying of polyethylene terephthalate on fibroblast cell adhesion. Radiat.Phys.

Chem. 67, 381-385 (2003).

[6] S. Myllymaa, K. Myllymaa, T. Sillat, H. Korhonen, R. Lappalainen and Y.T. Konttinen, Adhesion, spreading and osteogenic differentiation of mesenchymal stem cells cultured on micropatterned amorphous diamond, titanium, tantalum, and chromium coatings on silicon. J. Mater. Sci. Mater. Med. 21, 329-341 (2010).

[7] R.E. Baier, Surface behaviour of biomaterials: The theta surface for biocompatibility. J. Mater. Sci. Mater. Med. 17, 1057-1062 (2006).

[8] A. Carre and K.L. Mittal (Eds.) Surface and Interfacial Aspects of Cell Adhesion, CRC Press, Boca Raton, FL (2011). 
[9] S. Thakur and S. Neogi, Tailoring the adhesion of polymers using plasma for biomedical applications. Rev. Adhesion Adhesives. 3, 53-97 (2015).

[10] Q. Zhao, C. Wang and S. Liu, Bacterial adhesion on the metal-polymer composite coatings. Int. J. Adhesion Adhesives 27, 85-91 (2007).

[11] R.M. Donlan, RM. Biofilms: microbial life on surfaces. Emerging Infectious Diseases 8, 881-890 (2002).

[12] T.R. Scheuerman, A.K. Camper and M.A. Hamilton, Effects of Substratum Topography on Bacterial Adhesion. J. Colloid Interface Sci. 208, 23-33 (1998).

[13] V.K. Patel, A. Gupta, D. Singh, R. Kant and S. Bhattacharya, Surface functionalization to mitigate fouling of biodevices: A critical review. Rev. Adhesion and Adhesives. 3, 444-478 (2015).

[14] G. Yang, B. Wang, K. Vu, K. Tawfiq and G. Chen, Role of bacterial adhesion in their subsurface deposition and transport: A critical review. Rev. Adhesion Adhesives. 3, 16-52 (2015).

[15] D.G. Waugh and J. Lawrence, Laser Surface Treatment of a Polymeric Biomaterial: Wettability Characteristics and Osteoblast Cell Response Modulation, Old City Publishing, PA, USA (2013).

[16] K. Anselme, P. Davidson, A.M. Popa, M. Giazzon, M. Liley and L. Ploux, The interaction of cells and bacteria with surfaces structured at the nanometre scale. Acta Biomater. 6, 3824-3846 (2010).

[17] L.C. Hsu, J. Fang, D.A. Borca-Tasciuc , R.W. Worobo and C.I. Moraru, Effect of micro- and nanoscale topography on the adhesion of bacterial cells to solid surfaces. Appl. Environmen. Microbiol. 79, 2703-2712 (2013). [18] K.S. Tiaw, M.H. Hong and S.H. Teoh, Precision laser micro-processing of polymers. J. Alloys Compounds 449, 228-231 (2008).

[19] F.Z. Cui and Z.S. Luo, Biomaterials modification by ion-beam processing. Surf. Coat. Technol. 112, 278-285 (1999).

[20] E.S.A. Hegazy, H.A. AbdEl-Rehim, H. Kamal and K.A. Kandeel KA. Advances in radiation grafting. Nuclear Instrum. Meth. Phys. Res. B 185, 235-240 (2001).

[21] H. Mirzadeh, A.A. Katbab and R.P. Burford, CO2-laser graft copolymerization of HEMA and NVP onto ethylene-propylene rubber (EPR) as biomaterial-(III). Radiat. Phys. Chem. 46, 859-862 (1995).

[22] B. Rånby, Surface modification and lamination of polymers by photografting. Int. J. Adhesion Adhesive. 19, 337-343 (1999).

[23] M. Makropoulou, A.A. Seraftinides and C.D. Skordoulis. Ultra-violet and Infra-red Laser Ablation Studies of Biocompatible Polymers. Lasers Med. Sci. 10, 201-206 (1995).

[24] S. Cumming, BIO035E - The Global Market for Stem Cells, BCC Research Biotechnology Reports (2014).

[25] C. Wirth, C. Lagneau, P. Exbrayat, M. Lissac, N. Jaffrezic-Renault and L. Ponsonnet. Nitinol surface roughness moduluates in vitro cell responses: a comparison between fibroblasts and osteoblasts. Mater. Sci. Eng. C 25, 51-60 (2005).

[26] T.P. Kunzler, T. Drobek, J. Voros and N.D. Spencer, Systematic study of osteoblast response to nanotopography by means of nanoparticle-density gradients. Biomaterials 28, 5000-5006 (2007). 
[27] D.S. Kommireddy, S.M. Sriram, Y.M. Lvov and D.K. Mills, Stem cell attachment to layer-by-layer assembled TiO2 nanoparticle thin films. Biomaterials 27, 4296-4303 (2006).

[28] P. Stoodley, K. Sauer, D.G. Davies and J.W. Costerton, Biofilms as complex differentiated communities. Annu. Rev. Microbiol. 56, 187-209 (2002).

[29] J. Bourn, The Management and Control of Hospital Acquired Infection in Acute NHS Trusts in England, National Audit Office (2000).

[30] E.A. Vogler, Interfacial Chemsitry in Biomaterials Science, Marcel Dekker, New York, USA (1993).

[31] C.J. van Oss, Phagocytic Engulfment and Cell Adhesiveness, Marcel Dekker, New York, USA (1975).

[32] L. Hao and J. Lawrence, Laser Surface Treatment of Bio-Implant Materials, John Wiley \& Sons Inc., New Jersey, USA (2005).

[33] K. Kirchhof and T. Groth, Surface modification of biomaterials to control adhesion of cells. Clin. Hemorheol. Microcirc. 39 247-251 (2008). [34] J. Wei, D.B. Ravn, L. Gram and P. Kingshott, Stainless steel modified with poly(ethylene glycol) can prevent protein adsorption but not bacterial adhesion. Colloid Surf. B 32, 275-291 (2003).

[35] J M. Jelinek, P. Pisarik, T. Kocourek, J. Zemek, A. Kotzianova, K. Jurek, J. Miksovsky and T. Luxbacher, Preliminary comparative study of laserprepared DLC and Cr-doped DLC for bacteria adhesion. Appl. Phys. A 116, 1437-1443 (2014).

[36] D.G. Waugh and J. Lawrence, Wettability and osteoblast cell response modulation through UV laser processing of nylon 6,6. Appl. Surf. Sci. 257, 8798-8812 (2011).

[37] T.L. See, Z. Liu, S. Cheetham, S. Dilworth and L. Li . Laser abrading of carbon fibre reinforced composite for improving paint adhesion. Appl.

Phys. A 117, 1045-1054 (2014).

[38] M.L. Sushko and A.L. Shluger, DLVO theory for like-charged

polyelectrolyte and surface interactions. Mater. Sci. Eng. C 27, 1090-1095 (2007).

[39] A.E.C. Botero, M.L. Torem and L.M.S. de Mesquita, Surface chemistry fundamentals of biosorption of Rhodococcus opacus and its effect in calcite and magnesite flotation. Minerals Eng. 21, 83-92 (2008).

[40] J.M. Schakenraad, H.J. Busscher, C.R. Wildevuur and J. Arends, Thermodynamic aspects of cell spreading on solid substrata. Cell Biophys. 13, 75-91 (1988).

[41] M.G. Stewart, E. Moy, G. Chang, W. Zingg and A.W. Neumann, Thermodynamic model for cell spreading. Colloid Surf. 42, 215-232 (1989).

[42] W. Pfleging, M. Bruns, A. Welle and S. Wilson, Laser-assisted modification of polystyrene surfaces for cell culture applications. Appl. Surf. Sci. 253, 9177-9184.

[43] K. Page, M. Wilson and I.P. Parkin, Antimicrobial surfaces and their potential in reducing the role of the inanimate environment in the incidence of hospital-acquired infections. J. Mater. Chem. 19, 3819-3831 (2009). 
[44] W.M. Steen, K.G. Watkins and J. Mazumder, Laser Material Processing, 4th Edition, Springer, London, UK (2010).

[45] K.L. Mittal and T. Bahners (Eds.) Laser Surface Modification and Adhesion, Wiley-Scrivener, Beverly, MA (2015).

[46] J.C. Ion, Laser Processing of Engineering Materials: Principles,

Procedure and Industrial Application, Elsevier Butterworth-Heinemann ,Oxford, UK (2005).

[47] S.C. Chen, D.G. Cahill and C.P. Grigoropoulos, Melting and Surface Deformation in Pulsed Laser Surface Micromodification of Ni-P Disks. J. Heat Transf. 122, 107-112 (1999).

[48] J. Eizenkop, I. Avrutsky, G. Auner, D.G. Georgiev and V. Chaudhary V. Single pulse excimer laser nanostructuring of thin silicon films: Nanosharp cones formation and a heat transfer problem. J. Appl. Phys. 101, 094301 (2007).

[49] C.J. Duty and W.J. Lackey, Laser chemical vapour deposition: materials, modelling and process control. Int. Mater. Rev. 46, 271-281 (2001).

[50] E. Sarantopoulou, Z. Kollia, A.C. Cefalas, A.M. Douvas, M.

Chatzichristidi, P. Argitis and S. Kobe, Polymer self-assembled nanostructures and surface relief gratings induced with laser at $157 \mathrm{~nm}$. Appl. Surf. Sci. 253, 7884-7889 (2007).

[51] K. Callewaert, Y. Martelé, L. Breban, K. Naessens, P. Vandaele, R. Baets, G. Geuskens and E. Schacht, Excimer laser induced patterning of polymeric surfaces. Appl. Surf. Sci. 208-209, 218-225 (2003).

[52] W. Pfleging and M. Bruns, Laser-assisted modification of polystyrene surfaces for cell culture applications. Appl. Surf. Sci. 253, 9177-9184 (2007).

[53] A.C. Duncan, F. Weisbuch, F. Rouais, S. Lazare and C. Baquey, Laser microfabricated model surfaces for controlled cell growth. Biosensors Bioelectron. 17, 413-426 (2002).

[54] C. David, J. Wei, T. Lippert and A. Wokaun, Diffractive grey-tone masks for laser ablation lithography. Microelectron. Eng. 57-58, 453-460 (2001).

[55] L.D. Laude, D. Martinez, C.L. Dicara, F. Hanus and K. Kolev, The ablation of polymers under excimer laser irradiation: the physics of the process and the polymer structure. Nucl. Instrum. Meth. Phys. Res. B 185, 147-155 (2001).

[56] C.M. Chan, T.M. Ko and H. Hiraoka, Polymer surface modification by plasmas and photons. Surf. Sci. Rep. 24, 1-54 (1996).

[57] F. Yu, P. Li, H. Shen, S. Mathur, C.M. Lehr, U. Bakowsky and F. Mucklich, Laser interference lithography as a new and efficient technique for micropatterning of biopolymer surface. Biomaterials 26, 2307-2312 (2005).

[58] F. Yu, F. Mucklich, P. Li, H. Shen, S. Mathur, C.M. Lehr and U. Bakowsky, In vitro cell response to a polymer surface micropatterned by laser interference lithography. Biomacromolecules 6, 1160-1167 (2005). [59] S. Dadbin, Surface modification of LDPE film by CO2 pulsed laser irradiation. European Polym. J. 38, 2489-2495 (2002). 
[60] C.A. Aguilar, Y. Lu, S. Mao, S. Chen, Direct micro-patterning of biodegradable polymers using ultraviolet and femtosecond lasers. Biomaterials 26, 7642-7649 (2005).

[61] C.D. Skordoulis, M. Makropoulou and A.A. Serafetinides, Ablation of nylon-6,6 with UV and IR lasers. Appl. Surf. Sci. 86, 239-244 (1995).

[62] T. Lippert, J. Wei, A. Wokaun, N. Hoogen and O. Nuyken, Polymers designed for laser microstructuring. Appl. Surf. Sci. 168, 270-270 (2000). [63] V.D. Ta, A. Dunn, T.J. Wasley, R.W. Kay, J. Stringer, P.J. Smith, E. Esenturk, C. Connaughton and J. Shephard, Laser textured superhydrophobic surfaces and their applications for homogeneous spot deposition. Appl. Surf. Sci. 365, 153-159 (2016).

[64] F. Korte, J. Serbin, J. Koch, A. Egbert, C. Fallnich, A. Ostendorf and B.N. Chichkov, Towards nanostructuring with femtosecond laser pulses. Appl. Phys. A 77, 229-235 (2003).

[65] E. Stratakis, V. Zorba, M. Barberoglou, C. Fotakis and G.A. Shafeev, Femtosecond laser writing of nanostructures on bulk Al via its ablation in air and liquids. Appl. Surf. Sci. 255, 5346-5350 (2009).

[66] E. Fadeeva, V.K. Truong, M. Stiesch, B.N. Chichkov, R.J. Crawford, J. Wang and E.P. Ivanonva, Bacterial Retention on Superhydrophobic Titanium Surfaces Fabricated by Femtosecond Laser Ablation. Langmuir 27, 3012-3019 (2011).

[67] A. Carre and K.L. Mittal, Superhydrophobic Surfaces, CRC Press, Boca Raton, FL (2009).

[68] R.L. Harzic, M. Menzel, S. Henning, A. Heilmann, F. Stracke and H. Zimmerman, Cross-sectional study of high spatial frequency ripples performed on silicon using nanojoule femtosecond laser pulses at high repetition rate. Appl. Surf. Sci. 305, 670-673 (2014).

[69] A. Chebolu, B. Laha, M. Ghosh and Nagahanumaiah, Investigation on bacterial adhesion and colonisation resistance over laser-machined micro patterned surfaces. Micro and Nano Letters 8, 280-283 (2013).

[70] N. Hasan, J. Gopal and H.F. Wu, Surface pretreatment effects on titanium chips for the adhesion of pathogenic bacteria in the MALDI-TOF MS. Appl. Surf. Sci. 314, 52-63 (2014).

[71] B. Losekrug, A. Meschede and H.U. Krebs, Pulsed laser deposition of smooth poly (methyl methacrylate) films at $248 \mathrm{~nm}$. Appl. Surf. Sci. 254, 1312-1315 (2007).

[72] R. Cristescu, I. Stamatin, D.E. Mihaiescu, C. Ghica, M. Albulescu, I.N. Mihailescu, D.B. Chrisey, Pulsed laser deposition of biocompatible polymers: a comparative study in case of pullulan. Thin Solid Films 453454, 262-268 (2004).

[73] D.B. Chrisey and G.K. Hubler, Pulsed Laser Deposition of Thin Films, John Wiley, New York, USA (1994).

[74] G. Huang, Y. Chen and J. Zhang, Nanocomposite coating produced by laser-assisted process to prevent bacterial contamination and protein fouling. IEEE 144779054, 815-819 (2014). [75] L. Rusen, C. Mustaciosu, B. Mitu, M. Filipescu, M. Dinescu and V. Dinca, Protein-resistant polymer coatings obtained by matrix assisted pulsed laser evaporation. Appl. Surf. Sci. 278, 198-202 (2013). 
[76] J. Lawrence and L. Li, Modification of the wettability characteristics of polymethyl methacrylate (PMMA) by means of CO2, Nd:YAG, excimer and high power diode laser irradiation. Mater. Sci. Eng. A 303, 142-149 (2001). [77] D.G. Waugh and J. Lawrence, Laser Surface Engineering: Processes and Applications, Elsevier Ltd., Cambridge, UK (2015).

[78] D.G. Waugh, J. Lawrence and E.M. Brown, Osteoblast cell response to a CO2 laser modified polymeric material. Optics Lasers Eng. 50, 236-247 (2012).

[79] A. Gillett, D.G. Waugh and J. Lawrence, Laser Surface modification of polymeric materials for microbiological applications, in: Laser Surface Modification of Biomaterials: Techniques and Applications, R. Vilar and L. Overend (Eds.), Elsevier Ltd., Oxford, UK, In Press.

[80] H. Niino and A. Yabe, Chemical surface modification of fluorocarbon polymers by excimer laser processing. Appl. Surf. Sci. 96-98, 550-557 (1996).

[81] Y.C. Jung and B. Bhushan, Wetting transition of water droplets on superhydrophobic patterned surfaces. Scripta Mater. 57, 1057-1060 (2007).

[82] Y.C. Jung and B. Bhushan, Contact angle, adhesion and friction properties of micro- and nanopatterned polymers for superhydrophobicity. Nanotech. 17, 4970-4980 (2006).

[83] H.Y. Wang, J.Y. Zhao, Y.Z. Zhu, Y. Meng and Y.J. Zhu, The fabrication, nano/micro-structure, heat- and wear-resistance of the superhydrophobic PPS/PTFE composite coatings. J. Colloid Interface Sci. 402, 253-258 (2013).

[84] M. Hulander, A. Lundgren, L. Faxalv and T.L. Lindahl, Gradients in surface nanotopography used to study platelet adhesion and activation. Colloid Surf. B 110, 261-269 (2013).

[85] G. Esser, B. Jahrsdorfer and U. Urmoneit, Laser assisted fabrication of electronic circuits using the ADDIMID process. SPIE 4274, 375-384 (2001). [86] M.C. Sun, G. Kim, J.H. Lee, S.W. Kim and H.W. Kim, Patterning of Si nanowire array with electron beam lithography for sub-22nm Si nanoelectronics technology. J. Microelectron. Eng. 110, 141-146 (2013). [87] L.J. Guo, Nanoimprint lithography: Methods and material requirements. Adv. Mater. 19, 495-513 (2007).

[88] T. Higashiki, T. Nakasugi and I. Yoneda, Nanoimprint lithography for semiconductor devices and future patterning innovation. SPIE 7970, 797003 (2011).

[89] S.W. Ahn, K.D. Lee, J.S. Kim, S.H. Kim, J.D. Park and S.H. Lee, Fabrication of a $50 \mathrm{~nm}$ half-pitch wire grid polarizer using nanoimprint lithography. Nanotech. 16, 1874-1877 (2005). [90] S.H. Maruf, L. Wang, A.R. Greenberg, J. Pellegrino and Y. Ding, Use of nanoimprinted surface patterns to mitigate colloidal deposition on ultrafiltration membranes. J. Membrane Sci. 428, 598-607 (2013). [91] J.W. Ho, Q. Wee, J. Dumond, A. Tay amd S.J. Chu, Versatile pattern generation of periodic, high aspect ratio Si nanostructure arrays with sub50-nm resolution on a wafer scale. Nano. Res. Lett. 8, 506-516 (2013). 
[92] M.J. Dalby, M.O. Riehle, D.S. Sutherland, H. Agheli and A.S. Curtis AS. Changes in fibroblast morphology in response to nano-columns produced by colloidal lithography. Biomaterials 25, 5415-5422 (2004).

[93] M.J. Dalby, C.C. Berry, M.O. Riehle, D.S. Sutherland, H. Agheli and A.S. Curtis, Attempted endocytosis of nano-environment produced by colloidal lithography by human fibroblasts. Experimental Cell Res. 295, 387-394 (2004).

[94] H. Agheli, J. Malmstrom, P. Hanarp and D.S. Sutherland, Nanostructured biointerfaces. Mater. Sci. Eng. C 26, 11-17 (2006). [95] K.B. Lee, S.J. Park, C.A. Mirkin, J.C. Smith and M. Mrksich, Protein nanoarrays generated by dip-pen nanolithography. Science 295, 17021705 (2002).

[96] D. Qin, Y. Xi and G.M. Whitesides, Soft lithography for micro- and nanoscale patterning. Nature Protocols 5, 491-502 (2010).

[97] K.Y. Suh, J. Seong, A. Khademhosseini, P.E. Laibinis and R. Langer, A simple soft lithographic route to fabrication of poly(ethylene glycol) microstructures for protein and cell patterning. Biomaterials 25, 557-563 (2004).

[98] R.S. Kane, S. Takayama, E. Ostuni, D.E. Ingber and G.M. Whitesides, Patterning proteins and cells using soft lithography. Biomaterials 20, 23632376 (1999).

[99] M.J. Biggs, R.G. Richards, N. Gadegaard, C.D. Wilkinson and M.J. Dalby, Regulation of implant surface cell adhesion: characterization and quantification of S-phase primary osteoblast adhesions on biomimetic nanoscale substrates. J. Orthopaedic Res. 25, 273-282 (2007).

[100] M.J. Biggs, R.G. Richards, N. Gadegaard, C.D. Wilkinson and M.J. Dalby, The effects of nanoscale pits on primary human osteoblast adhesion formation and cellular spreading. Journal of materials science: Mater. Med. 18, 399-404 (2007).

[101] L.E. McNamara, R.J. McMurray, M.J.P. Biggs, F. Kantawong, R.O.C. Oreffo and M.J. Dalby, Nanotopographical Control of Stem Cell Differentiation. J. Tissue Eng. 2010 1-13 (2010).

[102] J.B. Recknor, J.C. Recknor, D.S. Sakaguchi and S.K. Mallapragada, Oriented astroglial cell growth on micropatterned polystyrene substrates. Biomaterials 25, 2753-2767 (2004). [103] J.S. Miller, M.I. Bethencourt, M. Hahn, T.R. Lee and J.L. West, Laserscanning lithography (LSL) for the soft lithographic patterning of celladhesive self-assembled monolayers. Biotechnol. Bioeng. 93, 1060-1068 (2006).

[104] L. Kailas, E.C. Ratcliffe, E.J. Hayhurst, M.G. Walker, S.J. Foster and J.K. Hobbs, Immobilizing live bacteria for AFM imaging of cellular processes. Ultramicroscopy 109, 775-780 (2009).

[105] J. Levon, K. Myllymaa, V.P. Kouri, R. Rautemaa, T. Kinnari, S.

Myllymaa, Y.T. Konittinen and R. Lappalainen, Patterned macroarray plates in comparison of bacterial adhesion inhibition of tantalum, titanium, and chromium compared with diamond-like carbon. J. Biomed.I Mater. Res. A 92, 1606-1613 (2010). 
[106] W.G. Koh, A. Revzin, A. Simonian, T. Reeves and M. Pishko, Control of mammalian cell and bacteria adhesion on substrates micropatterned with poly(ethylene glycol) hydrogels. Biomed. Microdev. 5, 11-19 (2003).

[107] N.B. Arnfinnsdottir, V. Ottesen, R. Lale and M. Sletmoen, The design of simple bacterial microarrays: Development towards immobilizing single living bacteria on predefined micro-sized spots on patterned surfaces. PloS one 10, 0128162 (2015).

[108] A.V. Singh, V. Vyas, T.S. Salve, D. Cortelli, D. Dellasega and A. Podesta et al., Biofilm formation on nanostructured titanium oxide surfaces and a micro/nanofabrication-based preventive strategy using colloidal lithography. Biofabrication. 4025001 (2012).

[109] A.Z. Komaromy, S. Li, H. Zhang, D.V. Nicolau, R.I. Boysen and M.T.W. Hearn, Arrays of nano-structured surfaces to probe the adhesion and viability of bacteria. Microelectron. Eng. 91, 39-43 (2012).

[110] L.C. Xu and C.A. Siedlecki, Submicron-textured biomaterial surface reduces staphylococcal bacterial adhesion and biofilm formation. Acta Biomater. 8, 72-81 (2012).

[111] P. Krsko, J.B. Kaplan and M. Libera M. Spatially controlled bacterial adhesion using surface-patterned poly(ethylene glycol) hydrogels. Acta Biomater. 5, 589-596 (2009).

[112] D. Nyamjav, S. Rozhok and R.C. Holz, Immobilization of motile bacterial cells via dip-pen nanolithography. Nanotech. 21, 235105 (2010). [113] C. Satriano, G.M.L. Messina, S. Carnazza, S. Guglielmino and G. Marletta, Bacterial adhesion onto nanopatterned polymer surfaces. Mater. Sci. Eng. C 26, 942-946 (2006).

[114] A. Cerf, J.C. Cau and C. Vieu, Controlled assembly of bacteria on chemical patterns using soft lithography. Colloid Surf. B 65, 285-291 (2008).

[115] F. Xu, S. Moon, A.E. Emre, C. Lien, E.S. Turali and U. Demirci, Cell bioprinting as a potential high-throughput method for fabricating cellbased biosensors (CBBs). Sensors, 2009 387-391 (2009).

[116] A. Ruiz, L. Buzanska, D. Gilliland, H. Rauscher, L. Sirghi, T. Sobanski, M. Zychowicz, L. Ceriotti, F. Bretagnol, S. Coeke, P. Colpo and F. Rossi, Micro-stamped surfaces for the patterned growth of neural stem cells. Biomaterials 29, 4766-4774 (2008).

[117] K. Shen, J. Qi and L.C. Kam, Microcontact printing of proteins for cell biology. J. Vis. exp. 22, 1065-1068 (2008).

[118] S.G. Ricoult, A.S. Nezhad, M. Knapp-Mohammady, T.E. Kennedy and D. Juncker, Humidified microcontact printing of proteins: universal patterning of proteins on both low and high energy surfaces. Langmuir 30, 12002-12010 (2014).

[119] G. Csucs, R. Michel, J.W. Lussi, M. Textor and G. Danuser, Microcontact printing of novel co-polymers in combination with proteins for cell-biological applications. Biomaterials 24, 1713-1720 (2003). [120] M.R. Dusseiller, D. Schlaepfer, M. Koch, R. Kroschewski and M. Textor, An inverted microcontact printing method on topographically structured polystyrene chips for arrayed micro-3-D culturing of single cells. Biomaterials 26, 5917-5925 (2005). 
[121] J.L. Charest, L.E. Bryant, A.J. Garcia and W.P. King, Hot embossing for micropatterned cell substrates. Biomaterials 25, 4767-4775 (2004).

[122] L. Filipponi, P. Livingston, O. Kaspar, V. Tokarova and D.V. Nicolau,

Protein patterning by microcontact printing using pyramidal PDMS stamps. Biomed. Microdev. 18 9-15 (2016).

[123] S. Catros, J.C. Fricain, B. Guillotin, B. Pippenger, R. Bareille, M. Remy, E. Lebraud, B. Desbat, J. Amedee and F. Guillemot, Laser-assisted bioprinting for creating on-demand patterns of human osteoprogenitor cells and nano-hydroxyapatite. Biofabrication 3, 025001/1-025001/11 (2011).

[124] S. Tasoglu and U. Demirci, Bioprinting for stem cell research. Trends Biotechnol. 31, 10-19 (2013).

[125] J. Merrin, S. Leibler and J.S. Chuang, Printing multistrain bacterial patterns with a piezoelectric inkjet printer. PloS One 2, 663-670 (2007). [126] J.A. Barron, R. Rosen, J. Jones-Meehan, B.J. Spargo, S. Belkin and B.R. Ringeisen, Biological laser printing of genetically modified Escherichia coli for biosensor applications. Biosen. Bioelec. 20, 246-252 (2004).

[127] W. Taylor, Technical Synopsis of Plasma Surface Treatments. Institute of Packaging Professionals, Gainesville, FL, USA: University of Florida, (2009).

[128] M. Strobel, C. Lyons and K.L. Mittal (Eds.) Plasma Surface Modification of Polymers: Relevance to Adhesion, CRC Press, Boca Raton, FL (1994).

[129] M. Thomas and K.L Mittal (Eds.) Atmospheric Pressure Plasma Treatment of Polymers: Relevance to Adhesion. Wiley-Scrivener, Beverly, MA (2013).

[130] G.H Hsiue, S.D. Lee, C.C. Wang, M.H. Shiue and P.C. Chang, Plasmainduced graft copolymerization of HEMA onto silicone rubber and TPX film improving rabbit corneal epithelial cell attachment and growth.

Biomaterials 15, 163-171 (1994).

[131] S.H. Hsu and W.C. Chen, Improved cell adhesion by plasma-induced grafting of L-lactide onto polyurethane surface. Biomaterials 21, 359-367 (2000).

[132] M. Crespin, N. Moreau, B. Masereel, O. Feron, B. Gallez and T. Vander Borght et al., Surface properties and cell adhesion onto allylamine-plasma and amine-plasma coated glass coverslips. J. Mater. Sci. Mater. Med. 22, 671-682 (2011).

[133] P. Hamerli, T. Weigel, T. Groth and D. Paul, Surface properties of and cell adhesion onto allylamine-plasma-coated polyethylenterephtalat membranes. Biomaterials 24, 3989-3999 (2003).

[134] F.R. Pu, R.L. Williams, T.K. Markkula and J.A. Hunt, Effects of plasma treated PET and PTFE on expression of adhesion molecules by human endothelial cells in vitro. Biomaterials 23, 2411-2428 (2002). [135] F.R. Pu, R.L. Williams, T.K. Markkula and J.A. Hunt, Expression of leukocyte-endothelial cell adhesion molecules on monocyte adhesion to human endothelial cells on plasma treated PET and PTFE in vitro.

Biomaterials 23, 4705-4718 (2002).

[136] S. Tajima, J.S. Chu, S. Li and K. Komvopoulos, Differential regulation of endothelial cell adhesion, spreading, and cytoskeleton on low-density 
polyethylene by nanotopography and surface chemistry modification induced by argon plasma treatment. J. Biomed. Mater. Res. A 84, 828-836 (2008).

[137] J. Yang, J. Bei and S. Wang, Enhanced cell affinity of poly (D,Llactide) by combining plasma treatment with collagen anchorage. Biomaterials 23, 2607-2614 (2002).

[138] F. Arefi-Khonsari, M. Tatoulian, F. Bretagnol, O. Bouloussa and F. Rondelez, Processing of polymers by plasma technologies. Surf. Coat. Technol. 200, 14-20 (2005).

[139] F. Milde, K. Goedicke and M. Fahland, Adhesion behavior of PVD coatings on ECR plasma and ion beam treated polymer films. Thin Solid Films 279, 169-173 (1996).

[140] R.M.A. Abdul majeed, A. Datar, S.V. Bhoraskar and V.N. Bhoraskar, Surface modification of polymers by atomic oxygen using ECR plasma. Nucl. Instrum. Meth. Phys. Res. B 258, 345-351 (2007).

[141] J.P. Chen and C.H. Su, Surface modification of electrospun PLLA nanofibers by plasma treatment and cationized gelatin immobilization for cartilage tissue engineering. Acta Biomater. 7, 234-243 (2011).

[142] J. Lai, B. Sunderland, J. Xue, S. Yan, W. Zhao, M. Folkard, B.D. Michael and $Y$. Wang, Study on hydrophilicity of polymer surfaces improved by plasma treatment. Appl. Surf. Sci. 252, 3375-3379 (2006).

[143] X. Wang and M.G. McCord, Grafting of poly(N-isopropylacrylamide) onto nylon and polystyrene surfaces by atmospheric plasma treatment followed with free radical graft copolymerization. J. Appl. Polym. Sci. 104, 3614-3621 (2007).

[144] L. Li, X. Liu, X. Dai, L. Li and Y. Chen, Surface wetting processing on BNNT films by selective plasma modes. Chinese Sci. Bulletin. 58 34033408 (2013).

[145] P.K. Chu, Enhancement of surface properties of biomaterials using plasma-based technologies. Surf. Coat. Technol. 201, 8076-8082 (2007). [146] Y. Xie, X. Liu, A. Huang, C. Ding and P.K. Chu, Improvement of surface bioactivity on titanium by water and hydrogen plasma immersion ion implantation. Biomaterials 26, 6129-6135 (2005).

[147] M.F. Maitz, R.W. Poon, X.Y. Liu, M.T. Pham and P.K. Chu, Bioactivity of titanium following sodium plasma immersion ion implantation and deposition. Biomaterials 26, 5465-5473 (2005).

[148] T.V. Ivanova, G. Baier, K. Landfester, E. Musin, S.A. Al-Bataineh, D.C. Cameron, T. Homola, J.D. Whittle and M. Sillanpaa, Attachment of Poly(Ilactide) Nanoparticles to Plasma-Treated Non-Woven Polymer Fabrics Using Inkjet Printing. Macromol. Biosci. 15, 1274-1278 (2015).

[149] S.K. Hendricks, C. Kwok, M. Shen, T.A. Horbett, B.D. Ratner and J.D. Bryers, Plasma-deposited membranes for controlled release of antibiotic to prevent bacterial adhesion and biofilm formation. J. Biomed. Mater. Res. 50, 160-170 (2000).

[150] J. Wang, N. Huang, C.J. Pan, S.C.H. Kwok, P. Yang, Y.X. Leng, J.Y. Chen, H. Sun, G.J. Wan, Z.Y. Liu and P.K. Chu, Bacterial repellence from polyethylene terephthalate surface modified by acetylene plasma immersion ion implantation-deposition. Surf. Coat. Technol. 186, 299-304 (2004). 
[151] K. Triandafillu, D.J. Balazs, B.O. Aronsson, P. Descouts, P. Tu Quoc, C. van Delden, H.J. Mathieu and H. Harms, Adhesion of Pseudomonas aeruginosa strains to untreated and oxygen-plasma treated poly(vinyl chloride) (PVC) from endotracheal intubation devices. Biomaterials 24, 1507-1518 (2003).

[152] J.E. Gray, P.R. Norton, R. Alnouno, C.L. Marolda, M.A. Valvano and K. Griffiths, Biological efficacy of electroless-deposited silver on plasma activated polyurethane. Biomaterials 24, 2759-2765 (2003).

[153] W. Zhang, P.K. Chu, J. Ji, Y. Zhang, X. Liu, R.K. Fu, P.C. Ha and W. Yan, Plasma surface modification of poly vinyl chloride for improvement of antibacterial properties. Biomaterials 27, 44-51 (2006).

[154] K. Bazaka, M.V. Jacob, R.J. Crawford and E.P. Ivanova, Plasmaassisted surface modification of organic biopolymers to prevent bacterial attachment. Acta Biomater. 7, 2015-2028 (2011).

[155] J. Wang, N. Huang, P. Yang, Y.X. Leng, H. Sun, Z.Y. Liu and P.K. Chu, The effects of amorphous carbon films deposited on polyethylene terephthalate on bacterial adhesion. Biomaterials 25, 163-170 (2004). [156] R.S. Benson, Use of radiation in biomaterials science. Nucl. Instrum. Meth. Phys. Res. B 191, $752-757$ (2002).

[157] C.Z. Mao, W.Zhu, C. Zhu, A. Shen and S. Lin, In vitro studies of platelet adhesion on UV radiation-treated nylon surface. Carbohyd. Polym. 59, 19-25 (2005).

[158] Z. Zhu and M.J. Kelley, Grafting onto poly(ethylene terephthalate) driven by 172 nm UV light. Appl. Surf. Sci. 252, 303-310 (2005).

[159] M. Charbonnier, M. Alami, M. Romand and J.P. Girardeau-Montaut, Laser-assisted grafting onto polycarbonate: application to metallization by chemical means. Appl. Surf. Sci. 252, 206-211 (1997).

[160] H. Mirzadeh, A.A. Katbab, M.T. Khorasani, R.P. Burford, E. Gorgin and A. Golestani, Cell attachment to laser-induced AAm- and HEMA-grafted ethylene-propylene rubber as biomaterial: in vivo study. Biomaterials 16, 641-648 (1995).

[161] A. Terada, A. Yuasa, S. Tsuneda, A. Hirata, A. Katakai and M. Tamada, Elucidation of dominant effect on initial bacterial adhesion onto polymer surfaces prepared by radiation-induced graft polymerization. Colloids Surf. B 43, 99-107 (2005).

[162] A. Terada, A. Yuasa, T. Kushimoto, S. Tsuneda, A. Katakai and M. Tamada, Bacterial adhesion to and viability on positively charged polymer surfaces. Microbiol. 152, 3575-3583 (2006).

[163] W. Lee, S. Furusaki, K. Saito and T. Sugo, Tailoring a brush-type interface favorable for capturing microbial cells. J. Colloid Interf. Sci. 200, 66-73 (1998).

[164] C.A. Nava-Ortiz, G. Burillo, A. Concheiro, E. Bucio, N. Matthijs, H. Nelis, T. Coenye and C. Alvarez-Lorenzo, Cyclodextrin-functionalized biomaterials loaded with miconazole prevent Candida albicans biofilm formation in vitro. Acta Biomater. 6, 1398-1404 (2010).

[165] N. Anjum, M.N. Bellon-Fontaine, J.M. Herry and A.M. Riquet, A novel process to develop modified polymeric surfaces for the analysis of bacterial adhesion: Surface properties and adhesion test. J. Appl. Polym.

Sci. 109, 1746-1756 (2008). 
[166] T.R. Rautray, R. Narayanan, T.Y. Kwon, K.H. Kim, Surface modification of titanium and titanium alloys by ion implantation. J. Biomed. Mater. Res.

B 93, 581-591 (2010).

[167] M.C. Porte-Durrieu, C. Aymes-Chodur, N. Betz, B. Brouillaud, F. Rouais and C. A Le Moel, Synthesis of biomaterials by swift heavy ion grafting: Preliminary results of haemocompatibility. Nucl. Instrum. Meth. B 131, 36-375 (1997).

[168] H.M. Eyssa, M. Osman, A. Kandil and M.M. Abdelrahman, Effect of ion and electron beam irradiation on surface morphology and optical properties of PVA, Nucl. Sci. Tech. 26, 060306/1 - 060306/6 (2015). [169] J.S. Cho, Y.W. Beag, S. Han, K.H. Kim, J. Cho and S.K. Koh, Hydrophilic surface formation on materials and its applications. Surf. Coat. Technol. 128-129, 66-70 (2000).

[170] C. Aubry, T. Trigaud, J.P. Moliton and D. Chiron, Polymer gratings achieved by focused ion beam. Synthetic Met. 127, 307-311 (2002). [171] M.W. Moon, S.H. Lee, J.Y. Sun, K.H. Oh, A. Vaziiri and J.W. Hutchinson, Wrinkled hard skins on polymers created by focused ion beam. PNAS 104, 1130-1133 (2007).

[172] S. Iwanaga, Y. Akiyama, A. Kikuchi, M. Yamato, K. Sakai and T. Okano, Fabrication of a cell array on ultrathin hydrophilic polymer gels utilising electron beam irradiation and UV excimer laser ablation. Biomaterials 26, 5395-5404 (2005).

[173] N.A. Trujillo, R.A. Oldinksi, H. Ma, J.D. Bryers, J.D. Williams and K.C. Popat, Antibacterial effects of silver-doped hydroxyapatite thin films sputter deposited on titanium. Mater. Sci. Eng. C 32, 2135-2144 (2012). [174] K.A. Whitehead, J. Colligon and J. Verran, Retention of microbial cells in substratum surface features of micrometer and sub-micrometer dimensions. Colloid Surf. B 41, 129-138 (2005).

[175] K.A. Whitehead, J.S. Colligon and J. Verran, The production of surfaces of defined topography and chemistry for microbial retention studies, using ion beam sputtering technology. Int. Biodeter. Biodegr. 54, 143-151 (2004).

[176] E.P. Ivanova, J. Hasan, H.K. Webb, G. Gervinskas, S. Juodkazis, V.K. Truong, A.H.F. Wu, R.N. Lamb, V.A. Baulin, G.S. Watson, J.A. Watson, D.E. Mainwaring and R.J. Crawford, Bactericidal activity of black silicon. Nat. Commun. 4, 1-7 (2013).

[177] P. Krsko, T.E. McCann, T.T. Thach, T.L. Laabs, H.M. Geller and M.R. Libera, Length-scale mediated adhesion and directed growth of neural cells by surface-patterned poly(ethylene glycol) hydrogels. Biomaterials 30, 721-729 (2009).

[178] S.D. Puckett, E. Taylor, T. Raimondo and T.J. Webster, The relationship between the nanostructure of titanium surfaces and bacterial attachment. Biomaterials 31, 706-713 (2010).

[179] R.M. Donlan and J.W. Costerton, Biofilms: Survival mechanisms of clinically relevant microorganisms. Clin. Microbiol. Rev. 15, 167-193 (2002).

[180] M.K. Faruque, K.M. Darkwa, C.Y. Watson, J.T. Waterman and D. Kumar, Synthesis, structure, and biocompatibility of pulsed laser- 
deposited TiN nanowires for implant applications. J. Biomed. Mat. Res. A 100, 1831-1838 (2012). 